\title{
Interference with Contract and Other Economic Expectancies: A Clash of Tort and Contract Doctrine
}

\author{
Harvey S. Perlman $\dagger$
}

$A$ has a contract with $B$. TP interferes with its performance, to $A$ 's economic detriment. $A$ might recover from $B$ for breach of contract, but prior to 1853 , in most circumstances, he could not recover against TP. In that year, Lumley $v$. Gye $e^{1}$ established a general principle of tort liability for intentionally interfering with a contract. Since Lumley, the interference tort has been applied evenwhere the interference is directed at an unenforceable contract or a relationship involving only an expectancy not yet formalized into a contract. ${ }^{2}$ Today, courts impose liability under the rubric of the interference tort in a variety of contexts, but they have failed to develop common or consistent doctrines.

The absence of a coherent doctrine is understandable. The idea that a person should not interfere with another's economic relationships is easier to expound in the abstract than to apply in the particular. The expectations of the parties and, therefore, the acceptability of an interference differ radically depending on the context, terms, and subject matter of the relationship-whether it

† Professor, University of Virginia Law School. Several persons commented on earlier drafts, including Tyler Baker, Thomas Bergin, Edmund Kitch, Jeffrey O'Connell, George Rutherglen, Stephen Saltzburg, and participants in the University of Virginia and University of Iowa Faculty Workshops. I am particularly indebted to Robert Scott and Charles Goetz for their assistance. Linda Williams, Virginia class of 1982, and David Rosengren, class of 1981, provided valuable research support. A Sesquecentennial Associateship with the University of Virginia Center for Advanced Studies aided me in completing this article.

12 El. \& Bl. 216, 118 Eng. Rep. 749 (Q.B. 1853).

2 Most jurisdictions agree that the lack of an enforceable agreement is no defense to a suit for tortious interference. See, e.g., Powell v. Leon, 172 Kan. 267, 270, 239 P.2d 974, 978 (1952); Daugherty v. Kessler, 264 Md. 281, 285, 286 A.2d 95, 97 (1972); Northern Plumbing \& Heating, Inc. v. Henderson Bros., 83 Mich. App. 84, 93, 268 N.W.2d 296, 299 (1978); Bynum v. Bynum, 87 N.M. 195, 197, 531 P.2d 618, 620 (Ct. App.), cert. denied, 87 N.M. 179, 531 P.2d 602 (1975). Contra, William S. Deckelbaum Co. v. Equitable Life Assurance Soc'y, 419 N.E.2d 228, 232 (Ind. Ct. App. 1981). With respect to prospective relationships, modern American tort doctrine uniformly imposes liability for some interferences. See generally W. Prosser, Handbook of the Law of Torts $\$ 130$, at 949-62 (4th ed. 1971); Restatkment (SECOND) OR TORTS $\S 766$ B (1979). 
is contractual, terminable at will, or merely prospective, and whether it deals with goods or personal services. Moreover, a person's economic relationships are so numerous and so interdependent with activities of others that some interference is inevitable. In addition, many of the activities that increase the risk of contract disruption have socially useful consequences. Offering someone a better deal may interfere with an existing contract, but it also is the essence of a competitive market.

The task of balancing these competing interests is more difficult because courts have paid too little attention to the interplay of tort and contract policies and the proper role of each in resolving interference cases. Tort-contract interplay occurs throughout the common law. Most often, as in determining liability for defective products, the two perspectives conflict, and courts must decide whether a collective allocation of loss (tort) should supersede a private allocation (contract). Interference cases present a subtler relationship-one in which tort law is applied to protect rather than to override the terms of a private relationship. Here, courts must blend rather than choose between tort and contract principles to develop a cohesive doctrine. Such a doctrine can be developed best by shifting the focus in interference cases from the fact of interference to the nature of the interfering act. Two distinct categories of interference cases then emerge: those in which the defendant's act of interference is independently unlawful, and those in which the defendant's behavior is otherwise lawful.

In this article, I propose an unlawful means test that restricts tort liability to those cases in which the defendant's act is independently wrongful. ${ }^{3}$ Part I reviews the history of the interference tort, the current confusion in the case law, and the approach of the Restatement (Second) of Torts. Part II explores the purpose of the interference tort and develops a framework for analyzing its proper reach that is sensitive to the interplay of tort and contract policies. Part III examines typical contexts in which the tort has been applied, demonstrating that the unlawful means test can advance both tort and contract objectives and lead to a consistent approach to interference cases. ${ }^{4}$

3 In a recent article, Professor Dan Dobbs for different reasons reaches approximately the same conclusion about the proper future of the interference tort. Dobbs, Tortious Interference with Contractual Relationships, 34 ARK. L. REv. 335 (1980). For an analysis of Dobbs's position, see note 131 infra.

- Two classes of cases closely allied to the tortious interference cases-labor and antitrust-are not discussed explicitly. The tort at one time was applied to labor union activity 


\section{The State of the LaW}

At common law, a master could recover for losses he suffered from torts committed against his servants; he also could recover in tort where a third party induced a servant to leave his employ. ${ }^{8}$ Other types of contracts were protected against interference by torts such as fraud and slander, ${ }^{8}$ but there was no general principle of tort liability for contract interference.

The modern tort of intentional interference with economic expectancies dates from the 1853 English case of Lumley v. Gye. ${ }^{7}$ In that case, Johanna Wagner, an opera singer, was induced by the offer of a higher fee to sing for Gye instead of performing her contract to sing for Lumley. ${ }^{8}$ The Queen's Bench held that a cause of action was stated ${ }^{\ominus}$ and announced a general rule of tort liability for "wrongfully and maliciously, or, which is the same thing, with notice," interrupting a personal service contract, regardless of the

because boycott is an interference with economic expectancies. See W. Prossar, supra note $2, \S 129$, at $946-47$. Labor activity now is largely within the exclusive domain of federal labor law. See Restatement (Second) or Torts introductory note to div. 9, at 2 (1979). The preemption rule applied in the labor cases mirrors the distinction between lawful and unlawful means, argued here as a critical element in evaluating interference cases. In Farmer v. United Bhd. of Carpenters Local 25, 430 U.S. 290, 298-300 (1977), the Supreme Court held that state tort claims arising from labor disputes are preserved if based on the state's interest in protecting citizens from violence, defamation, or abuse-interests protected by traditional tort doctrine. Tort claims dependent on the merits of a labor dispute are preempted. San Diego Bldg. Trades Council v. Garmon, 359 U.S. 236 (1959). State courts therefore would seem to retain power only over interferences by acts independently unlawful.

The other excluded cases involve application of the antitrust laws where refusals to deal are used to advance anticompetitive objectives. See, e.g., United States v. Parke, Davis \& Co., 362 U.S. 29, 45-46 (1960). The first Restatement of Torts included sections on individual and concerted refusals to deal as well as on inducing refusals to deal. RESTATEMERT or TORTs $\$ \$ 762,765,766$ (1939). Sections 762 and 765 were supplanted by the provisions on intentional interference in the Restatement (Second). RESTATEMENT (SzCOND) or TorTs introductory note to div. 9 , at 2 (1979).

- See Sayre, Inducing Breach of Contract, 36 Harv. L. Rev. 663, 665 (1923). Early English common law gave a master a cause of action for physical violence inflicted on his servants. See id. Later a statute gave the master an action against a third person who, by nonviolent means, enticed the master's servant to leave his employ. The Ordinance of Labourers, 1349, 23 Edw. III (repealed by The Statute Law Revision Act, 1863, 26 \& 27 Vict., ch. 125). Professor Sayre concluded that lawyers and judges so badly confused the two actions that they merged. Sayre, supra, at 666.

- The early history is traced in Note, Tortious Interference with Contractual Relations in the Nineteenth Century: The Transformation of Property, Contract, and Tort, 93 HaRv. L. REv. 1510, 1511-21 (1980).

7 2 El. \& Bl. 216, 118 Eng. Rep. 749 (Q.B. 1853).

- See Lumley v. Wagner, 91 Rev. Rep. 193, 193-95 (Ch. 1852).

- Lumley v. Gye, 2 El. \& Bl. at 231, 118 Eng. Rep. at 755 (Erle, J.). 
means used. ${ }^{10}$ The court also hinted that the principle might be applied more broadly in the future. ${ }^{11}$ Later cases applied the tort to a variety of contracts and extended it to prospective relationships not yet formalized into contract. ${ }^{12}$ The cases also developed privileges for contract interference. ${ }^{13}$

Despite this long history, doctrinal confusion is pervasive, both within and among jurisdictions. In 1923, Professor Francis Bowes Sayre lamented that "where the doctrine has been accepted, there has been so little careful inquiry as to its precise limits and fundamental nature that a somewhat uncertain law has resulted."14 More than fifty years later, in 1979, the American Law Institute approved a restatement of the interference doctrine, ${ }^{18}$ but only after considerable debate and with some reluctance. ${ }^{16}$ Even then, the drafters conceded that the "law in this area has not fully congealed but is still in a formative stage."17

Most jurisdictions limit recovery to "intentional" interfer-

10 Id. at 224, 118 Eng. Rep. at 752 (Crompton, J.).

11 Id. at 224-25, 118 Eng. Rep. at 753 (Crompton, J.) (interference tort applies "wherever" the defendant's act "operates to prevent the service during the time for which the parties have contracted that the service shall continue"). In one writer's view, the Lumley decision transformed the law in three ways: executory contracts were protected from interference by persuasion; employment relationships other than formal master-servant relationships were protected from enticement by third parties; and a general protection against contract interference was announced, setting the stage for expansion to all types of contracts. Note, supra note 6, at 1522-23.

${ }_{12}$ See text and note at note 2 supra.

${ }_{13}$ See Carpenter, Interference with Contract Relations, 41 HARv. L. REv. 728, 745-62 (1928), and authorities cited therein. For a historical explanation for the development of the privilege of competition, see Note, supra note 6, at 1529-37. For a discussion of some specific privileges, see text and notes at notes 47-54 infra.

14 Sayre, supra note 5 , at 672.

15 Restatement (Second) of Torts §§ 766-774A (1979).

${ }^{26}$ In 1969, Dean William Prosser presented a proposed draft on "Interference with Business Relations" for inclusion in the Restatement (Second) of Torts. Id. (Tent. Draft No. 14, 1969). After lengthy and heated discussion on the floor of the American Law Institute, Prosser concluded that the draft needed further study. See id. at vii (Tent. Draft No. 23, 1977) (Foreword, H. Wechsler). After the rest of the Restatement (Second) had been approved, it was discovered that chapter 37 , the material on interference, had not been resubmitted to the Institute for approval. Dean John Wade, then reporter for the project, presented a major reformulation to the Institute in 1977. Id. Herbert Wechsler advised the Institute that it was "essential to perfect [the draft] at this meeting, since the rest of volume IV of the Torts Restatement, Second, is now ready for the press." Id.

17 Restatement (SeCond) of TorTs introductory note to ch. 37, at 5 (1979). English law apparently has fared no better. See Stevens, Interference with Economic Relations-Some Aspects of the Turmoil in the Intentional Torts, 12 Osgoode HaLl L.J. 595, 595 (1974) (observing that tort liability for interference with economic interests has "developed in an illogical and piecemeal fashion, with the result that, today, many of the principles concerning the intentional torts are still unclear"). 
ences, ${ }^{18}$ but the definition of "intent" continues to be disputed. A specific intent to disrupt the relationship in question normally is actionable, but an act that is substantially certain to lead to a contract disruption is not always actionable where the actor's motive is unrelated to the contract. ${ }^{10}$ In addition, courts disagree on such fundamental matters as what type of contracts are protected,,$^{20}$ what behavior resulting in interference is actionable, ${ }^{21}$ and what remedy is appropriate. ${ }^{22}$

The most significant disagreement concerns the burden of proof. The general rule is that the plaintiff's proof of an intentional act resulting in disruption of an economic relationship constitutes a prima facie case of liability, casting upon the defendant the burden of proving that the interference was justified. ${ }^{23}$ The issue is more than procedural, as a recent Alaska case illustrates. ${ }^{24}$ The defendant, Alyeska Pipeline, contracted with RCA, which in turn contracted with the plaintiff, Aurora Air Service, to provide services necessary for RCA to fulfill its contract with Alyeska. All of the contracts were terminable at will. When Alyeska modified its contract with RCA, RCA was forced to terminate its contract with Aurora. Aurora alleged that Alyeska had initiated this chain of events to harm Aurora and claimed contract interference. ${ }^{25}$ The trial court gave judgment for Aurora, and the Alaska Supreme Court affirmed. The supreme court held that a prima facie case of

18 See W. Prosser, supra note $2, \S 129$, at 938-41.

10 Dean Prosser, as reporter for the Restatement, was frustrated by his inability to distinguish between the law's unwillingness to allow a life insurance company to recover from the murderer of its insured, even though the murderer knew of the insurance contract, and cases allowing a broker to recover against a third party for loss of commission, where the third party knew of the brokerage contract and induced its breach. See 46 ALI Prockedings 180-81 (1969) (statement of Dean Prosser) ("Some of these cases say there is liability; some of these cases say there is not. And I am defeated when I try to find any kind of pattern among the group. The courts have apparently acted very largely on the impulse of the moment, and nowhere in any of these cases is there any discussion of this particular problem or what you should do about it."). See also note 189 infra.

${ }^{20}$ At least one jurisdiction requires a valid, enforceable contract. In others, lack of an enforceable agreement is no defense. See cases cited supra note 2.

${ }^{21}$ Most cases hold that any intentional, unprivileged interference is actionable; a few have required that the interfering act be wrongful by some measure other than the interference alone. See text and notes at notes 24-31 infra.

22 See Restatement (Second) of TorTs \& 774A (1979) (tort measure of damages). Contra, Armendariz v. Mora, 553 S.W.2d 400, 406 (Tex. Civ. App. 1977) (contract measure of damages applied, with breacher and inducer jointly and severally liable).

${ }^{33}$ W. Prosskr, supra note $2, \S 129$, at 942-43.

${ }^{24}$ Alyeska Pipeline Serv. Co. v. Aurora Air Serv. Inc., 604 P.2d 1090 (Alaska 1979).

${ }^{25}$ Id. at 1092-93. 
tort liability was established by proof that a contract was intentionally disrupted. The court also held that Alyeska had the burden of establishing that it had acted in "good faith"- -that is, that it was motivated by its own economic interest rather than an intent to harm Aurora. ${ }^{28}$ In a case of mixed motives, the trier of fact was to determine the predominant purpose. ${ }^{27}$ Observing that the "evidence was susceptible to varying interpretations on the questions of good faith, justification, and motive," the court upheld the jury verdict for Aurora ${ }^{28}$ and approved an instruction authorizing punitive damages. ${ }^{2 \theta}$

Cases like Alyeska appear to view economic relationships as comparable to property rights: prima facie liability is established by the fact of intentional interference with the plaintiff's economic interest rather than by the nature of the interfering act. ${ }^{30}$ To escape liability, the interfering party then must prove some overriding justification for his interference. In a recent departure from this traditional analysis, the Oregon Supreme Court required the plaintiff to demonstrate some wrong beyond the mere fact of interference. $^{31}$ The court rejected the more general theory of intentional interference because of "the difficulties of defining the elements of so general a tort without sweeping within its terms a wide variety of socially very different conduct." ${ }^{32}$ A few other courts had earlier

${ }^{28}$ Id: at $1095-96$ \& n.7.

${ }^{27}$ Id. at 1093 (quoting W. Prosser, supra note 2, § 129, at 943). It has been observed that Alaska's predominant purpose test requires liability even where a rational nonmalicious person would have acted similarly. Dobbs, supra note 3 , at 349 .

${ }^{28} 604$ P.2d at 1094 .

${ }^{29}$ Id. at 1098.

so See, e.g., Pre-Fit Door, Inc. v. Dor-Ways, Inc., 13 Ariz. App. 438, 440-41, 477 P.2d 557, 559-60 (1970); Symon v. J. Rolfe Davis, Inc., 245 So. 2d 278, 280 (Fla. Dist. Ct. App. 1971); Frost Nat'l Bank v. Alamo Nat'l Bank, 421 S.W.2d 153, 156 (Tex. Civ. App. 1967); see also W. Prosser, supra note $2, \S 129$, at 943 , and authorities cited therein.

s1 [A] claim [of tortious interference] is made out when interference resulting in injury to another is wrongful by some measure beyond the fact of the interference itself. Defendant's liability may arise from improper motives or from the use of improper means. They may be wrongful by reason of a statute or other regulation, or a recognized rule of common law, or perhaps an established standard of trade or profession. No question of privilege arises unless the interference would be wrongful but for the privilege; it becomes an issue only if the acts charged would be tortious on the part of an unprivileged defendant.

Top Serv. Body Shop, Inc. v. Allstate Ins. Co., 283 Or. 201, 209-210, 582 P.2d 1365, 1371 (1978) (en banc) (citations omitted). See also Inventive Music Ltd. v. Cohen, 617 F.2d 29, 34 (3d Cir. 1980) (applying New Jersey law) (interference must be violative of "generally accepted standards of common morality or law").

32 283 Or. at 205,582 P.2d at 1368 (footnote omitted). 
announced a requirement that the plaintiff demonstrate some independently wrongful act, but most of these decisions have been overruled. ${ }^{\text {ss }}$

The gulf between these approaches explains the ambivalence with which the American Law Institute restated the law. Under the Restatement (Second), the interference tort applies to all contracts, even those that are terminable at will, voidable, or unenforceable by operation of law; $;^{34}$ only void contracts are excluded from protection against interference. ${ }^{\text {s5 }}$ The Restatement (Second) also applies the tort to prospective relations not yet formalized into contract. ${ }^{38}$ The keystone of the Restatement (Second) treatment of tortious interference is the provision that the defendant is liable only if his interference is "improper."37 The drafters used the term to avoid any implication regarding burdens of proof, noting that liability depends "upon the interplay of several factors ... not reducible to a single rule" and that "there is considerable disagreement on who has the burden of pleading and proving certain matters." 38 To determine whether an interference is improper, the Restatement (Second) instructs courts to balance seven factors: ${ }^{38}$ the actor's conduct, ${ }^{40}$ the actor's motive, ${ }^{41}$ the interest inter-

ss See Annot., 26 A.L.R.2d 1227, $1251-53$ (1952). See also Dependahl v. Falstaff Brewing Corp., 653 F.2d 1208, 1217 (8th Cir. 1981), recognizing limits to the tort of intentional interference and citing, among other sources, an earlier draft of this article.

s4 Restatement (SECOND) of ToRTs $\$ 766$ (1979). Void contracts are those with no legal effect. A gambling contract void as against public policy is an example. A voidable contract is one in which at least one of the parties has the power to avoid, but the contract is enforceable until that power is exercised. A contract with an infant is the paradigm. An unenforceable contract is an otherwise lawful contract that by operation of law-such as the statute of frauds or statute of limitations-is not legally enforceable. See generally $1 \mathrm{~A}$. CoRBIn, CoRBIN on Contracts $\$ \S 6-8$ (1963). As to voidable and unenforceable contracts, the Restatement (Second) provides that the third party "is not . . . for that reason free to interfere with performance of the contract before it is avoided." RESTATEMENT (SECOND) or TorTs $\S 766$ comment $\mathrm{f}$ (1979). Contracts terminable at will are similarly protected. Id. comment $\mathrm{g}$.

ss Restatement (Second) of ToRTs \$ 774 (no liability for causing the "nonperformance of an illegal agreement" by "appropriate means"). Comment b explains that void contracts are not within the rules of interference with performance because they are not contracts at all. In addition to contracts involving moral turpitude, other types of contracts have been considered void and thus outside the protection of the interference tort. See id. \& 766 comment f; Jolma v. Steinbock, 596 P.2d 980, 984-85 (Or. Ct. App. 1979) (real estate commission agreement with unlicensed broker). Whether there is liability in a case where the third party upsets a void contract by fraudulent means is uncertain.

36 Restatrment (SECOND) of ToRTs \& 766B (1979).

${ }^{37} \mathrm{Id}$. introductory note to $\mathrm{ch} .37$, at 6 .

ss Id. at 5 .

30 Id. § 767. 
fered with, ${ }^{42}$ the interest advanced by the actor, ${ }^{48}$ society's interests, ${ }^{44}$ the proximity of the actor's conduct to the interference, ${ }^{45}$ and the parties' relations. ${ }^{48}$ The list is hardly limiting or edifying. The Restatement (Second) also sets forth specific rules for interests likely to be asserted as justifying particular interferences. On the theory that the "social interest in the security of transactions . . . outweighs the interests in [the inducer's] freedom of action," "17 the Restatement (Second) provides that competition between the plaintiff and defendant does not justify interference with existing contracts. ${ }^{48}$ Competitive interferences with contracts terminable at will and prospective relationships, however, are permitted. ${ }^{49}$ Various other interferences are permitted as long as wrongful means are not used. A person with a financial interest in another's business can induce him to avoid a prospective relationship but not an existing contract. ${ }^{.0} \mathrm{~A}$ person charged with another's welfare can induce him to breach an existing contract or to

10 Id. § 767(a). The "nature of the actor's conduct" is regarded as "a chief factor" but not the only factor in determining impropriety. Id. \& 767(a) comment c, at 29. The comment notes that although violence, fraud, and other wrongful behavior "ordinarily" may make the interference improper, innocent means also may subject the actor to liability.

${ }^{41} I d$. \& 767(b). If the actor's "sole" motive is to interfere, the interference "is almost certain to be held improper." Id. $\S 767$ (b) comment d, at 32 . Mixed motivations must be balanced. Id. comment d, at 32-33.

12 Id. $\S 767$ (c) This factor is seen as relating to the nature of the contract (prospective or existing), as well as to the object of the contract (for example, whether it is against public policy). Id. \& 767 (c) comment e, at 34 .

43 Id. § 767(d).

14 Id. \& 767(e). The rationale for considering social interests is that "[a]ppraisal of the private interests of the persons involved may lead to a stalemate unless the appraisal is enlightened by a consideration of the social utility of these interests." Id. § 767(e) comment $\mathrm{g}$, at 35 .

15 Id. § 767(f).

48 Id. $\S 767(\mathrm{~g})$. Thus, if TP is $A$ 's business adviser, the Restatement (Second) suggests that it may be proper for $T P$ to advise $A$ to break his contract with $B$ for financial reasons, whereas such advice might be improper if $T P$ is a volunteer. $I d . \$ 767(\mathrm{~g})$ comment $\mathrm{i}$, at 36 .

17 Id. § 768(2).

18 Id. $\$ 768(2)$ comment $\mathrm{h}$, at 43 .

19 Id. $\S 768(1)$. It is not clear whether this limited competitive privilege is intended to apply to a third person who is not in direct competition with either party, but who nonetheless interferes to advance competition (and his own interest).

so Id. § 769. A stockholder or other investor may have sufficient interest to persuade a business entity not to enter a prospective contractual relationship. Id. $\S 769$ comment c, at 45. See Fury Imports, Inc. v. Shakespeare Co., 554 F.2d 1376, 1383-85 (5th Cir. 1977) (applying New York law), in which the privilege was recognized as applying even to interference with existing contracts. The court nonetheless held a stockholder's interference improper because it seemed to go against the corporation's financial interest and thus was not calculated to protect the stockholder's ownership interest. 
avoid a prospective relationship. ${ }^{\text {s1 }}$ A person can attempt to influence another's business policy as long as he has an economic interest in the policy and the policy does not unlawfully restrain trade $^{.22}$ A person can give honest advice or truthful information ${ }^{\text {ss }}$ and may assert a legal interest of his own in good faith, even though such actions interfere with an existing contract or prospective relationship. ${ }^{54}$

\section{The Proper Scope of the Interference Tort}

\section{A. Interference by Means Otherwise Unlawful}

The tort of intentional interference with contracts and prospective relationships consistently has been applied where the defendant's behavior is independently unlawful.s5 Thus, if $A$ has a contract with $B$, and $T P$ by fraud causes $A$ not to perform, thereby injuring $B, B$ may have a claim of contract interference..$^{B B}$ In such a case, the interference tort provides an alternative to a claim based directly on the underlying unlawful behavior. The tort is understood best in these cases by examining why courts would be reluctant to award contractually related damages under the heading of traditional intentional torts such as fraud, and why they have been willing in restricted circumstances to allow recovery under the rubric of intentional interference instead.

6 Restatement (Second) of Torts \$ 770. Examples of relationships to which this privilege might apply include parent and child, attorney and client, and employer and employee. Id. $\$ 770$ comment b, at $46-47$.

s2 Id. § 771. The section seems to refer to boycotts or refusals to deal, whether individual or concerted. Id. $\$ 771$ comment c, at 49 .

${ }^{83} I d$. $\$ 772$. The effect of this section is unclear. The drafters state that there can be no liability for giving truthful information, id. $\$ 772$ comment $b$, at 50 , but the line between providing information and inducing breach is fine. Truthful information presumably could include the statement, "If you break your contract, I will offer you employment at a higher wage."

s4 Id. § 773. The most common illustration of this privilege is where $A$ and $B$ both contract to buy the same horse from $C$. $A$ may induce $C$ to deliver the horse to him, even if $A$ knows it means $C$ will breach his contract with $B$. Id. $\$ 773$ comment a, illustration 3 .

${ }^{\text {ss }}$ A good example of a tortious interference complaint coupled with allegations of independently unlawful behavior is reported in Lekich v. IBM Corp., 469 F. Supp. 485 (E.D. Pa. 1979). After alleging defamation, intentional infliction of emotional distress, and wrongful discharge by his employer, the plaintiff alleged that "IBM tortiously interfered with plaintiff's prospective contractual relationships by publishing defamatory statements and terminating his employment." Id. at 489. See also South Cent. Livestock Dealers, Inc. v. Security State Bank, 551 F.2d 1346, 1350-51 (5th Cir. 1977) (applying Texas law) (tortious interference claimed on basis of bank's independently wrongful offset of trust funds).

se See text and notes at note 73-74 infra. 
In most tortious interference cases, the plaintiff's loss is purely economic. Personal injury or property damage, the normal grist of tort law, is rarely involved. As a general proposition, tort recovery for pure economic loss unaccompanied by personal injury or property damage is carefully restrained; a few intentional torts such as fraud protect against economic loss, but are structured rigidly to restrict recovery. ${ }^{57}$ For other intentional torts, third-party contractual interests are not protected, and in negligence cases, pure economic loss seldom is compensated..$^{58}$ The articulated justification for denying recovery is that such losses are remote or unforeseeable, ${ }^{50}$ but this explanation hides more than it illuminates. ${ }^{60}$ An understanding of why economic loss poses such difficulties helps explain the development of the contract interference tort.

1. Economic Loss and Limits to Liability. The consequences of any act can be traced indefinitely, but tort law has never made a defendant pay for all harm caused by his tortious act, however remote. At some point, it is generally agreed that the defendant's act cannot fairly be singled out from the multitude of other events that combine to cause loss. A number of doctrinal devices - proximate cause, intervening cause, and duty-have served to limit liability.

From an instrumentalist perspective, the extension of liability increases the likelihood of at least three undesirable consequences. First, as the amount of potential liability increases, an actor must attach greater significance to the risk that the substantive legal rule will be applied erroneously or that he mistakenly will cross the

${ }_{57}$ See, e.g., Stevenson v. Eastern Ohio Gas Co., 73 N.E.2d 200, 203-04 (Ohio Ct. App. 1946); see also W. Prosser, supra note 2, § 112, at 760-61; Restatement (SeCOND) of TorTS $\S 766 \mathrm{C}$ (1979); text and notes at notes 73-75 infra.

ss See W. Prosser, supra note $2, \S 130$, at 952 , and authorities cited therein.

so See, e.g., Rickards v. Sun Oil Co., 23 N.J. Misc. 89, 94-95, 41 A.2d 267, 269 (Sup. Ct. 1945). See also W. Prosser, supra note $2, \S 129$, at 940.

${ }^{B 0}$ Where personal injury or property damage result, economic expectancy loss is recoverable. See generally 22 AM. Jur. 2D Damages $\$ \S 89,138$ (1965). The loss of future earning capacity, for example, is a standard element of personal injury recoveries. See, e.g., Newlin v. New Eng. Tel. \& Tel. Co., 316 Mass. 234, 235-37, 54 N.E.2d 929, 930-31 (1944). Where recovery of economic loss is denied, fear of fraud and the costs of measurement cannot be the sole reasons; compared to many other losses compensated in tort, economic expectancy loss can be easily proved and measured. Cf. Capelouto v. Kaiser Found. Hosps., 7 Cal. 3d 889, 898, 500 P.2d 880, 886-87, 103 Cal. Rptr. 856, 862-63 (1972) (en banc) (jury instruction precluding pain and suffering damages for a one-year-old child held erroneous); Moorhead v. State Dep't of Highways, 353 So. 2d 1103, 1105 (La. Ct. App. 1977) (plaintiff allowed damages for mental anguish caused by witnessing a trespassing bulldozer remove five trees from her property). 
line from no liability to liability. This increased cost of error may inhibit socially useful activity. The problem is most acute where liability is based on negligence, because the line between careless and careful behavior is ambiguous. Courts thus tend to delimit liability more strictly for negligence than for intentional torts, where in many instances the line between lawful and unlawful behavior is clear.

Second, tort law may attempt to regulate the level of risky activity by internalizing its costs. As a loss becomes more remote from the defendant's act, the loss is more likely to be a cost attributable to intervening forces. Also, it is less likely that the defendant will regulate his activity to account for remote or unforeseeable losses. Third, as more losses are brought within the ambit of liability, the administrative costs of the legal system increase. On the other hand, limiting liability may reduce incentives to be careful. ${ }^{61}$

There is little agreement on where to draw the line. Recent tort scholarship has offered a variety of plausible explanations for the need to limit liability, ${ }^{62}$ but none offers more than a general approach for establishing the precise limit. Moreover, courts faced with the problem of limiting liability in individual cases have concerns beyond locating the limit at precisely the right point. They can be expected to search for a rule that can be applied consistently and articulated sensibly to guide future cases and to avoid the appearance of arbitrariness.

In cases of physical injury to persons or property, the task of defining liability limits is eased, but not eliminated, by the operation of the laws of physics. Friction and gravity dictate that physical objects eventually come to rest. The amount of physical damage that can be inflicted by a speeding automobile or a thrown fist has a self-defining limit. Even in chain reaction cases, intervening

61 This analysis of the costs of expanded liability is based in part on the more detailed evaluation of causation in Shavell, An Analysis of Causation and the Scope of Liability in the Law of Torts, 9 J. Legal Stud. 463 (1980).

62 Professor Guido Calabresi offers a helpful analysis of the role of proximate cause in reaching various instrumentalist objectives in tort cases in Concerning Cause and the Law of Torts: An Essay for Harry Kalven, Jr., 43 U. CHI. L. REv. 69 (1975). See also R. KBBTon, Legal Cause IN the Law of ToRts (1963). In contrast, Professor Richard Epstein's strict liability system, based on corrective justice, depends on causation to trigger liability. Even so, it seems clear that Epstein would not attach liability to all losses in some way causally linked to the defendant's act, but would require rather that the loss fit one of four proposed paradigms of causation that in his formulation seem to limit liability. Epstein, $A$ Theory of Strict Liability, 2 J. Legal Stud. 151, 160-89 (1973). 
forces generally are necessary to restore the velocity of the harmcreating object. These intervening forces offer a natural limit to liability.

The laws of physics do not provide the same restraints for economic loss. Economic relationships are intertwined so intimately that disruption of one may have far-reaching consequences. Furthermore, the chain reaction of economic harm flows from one person to another without the intervention of other forces. ${ }^{63}$ Courts facing a case of pure economic loss thus confront the potential for liability of enormous scope, with no easily marked intermediate points $^{64}$ and no ready recourse to traditional liability-limiting devices such as intervening cause.

The practical problem of limiting recovery for economic loss seems to explain several features of traditional intentional tort doctrine. The common law normally did not allow a plaintiff to recover economic loss resulting from a physical tort by the defendant against a third person. ${ }^{65}$ Only in a few situations, where the

${ }^{63}$ Assume that $A$ 's economic relationship with $B$ depends on $B$ 's relationship with $C$, which depends on $C$ 's relationship with $D$. An act by $D$ directed at his relationship with $C$ may cause $A$ loss. Courts could declare $C$ 's action an intervening cause and limit $D$ 's liability to $C$ 's loss; such is the thrust of the contract rule of Hadley v. Baxendale, $9 \mathrm{Ex}$. 341, 354-355, 156 Eng. Rep. 145, 151 (1854). But if $X$ performs an act directed at $D$ that causes $D$ to disrupt his relationship with $C$, thereby setting off a chain reaction that causes $A$ loss, it is difficult to articulate a distinction among the behavior of $D, C$, and $B$ that would justify holding $X$ liable only to $D$ and not to $A, B$, and $C$ as well.

64 An illustration of this problem is Union Oil Co. v. Oppen, 501 F.2d 558 (9th Cir. 1974), in which the court ignored the traditional restraints on liability for loss of economic expectancies by allowing fishermen to recover for loss of their prospective catch caused by an oil spill. The fishermen suffered no physical harm to their property because they had only an expectancy and not a property right in the uncaught fish. The court did not explain satisfactorily why its holding was limited to the fishermen's losses and did not apply to "every decline in the general commercial activity of every business in the Santa Barbara area." Id. at 570. See also J'Aire Corp. v. Gregory, 24 Cal. 3d 799, 805, 598 P.2d 60, 64, 157 Cal. Rptr. 407, 411 (1979), where a lessee was allowed to recover for loss associated with the disruption of his business caused by a contractor, hired by the lessor, who negligently delayed repairs to the leased premises. The "slippery slope" restraint on proximate cause analysis was recognized and applied in Hartridge v. State Farm Mut. Auto. Ins. Co., 86 Wis. 2d 1, 11-13, 271 N.W.2d 598, 602-03 (1978), in which an employer unsuccessfully sought recovery for loss associated with injury of an employee by the defendant's negligence.

es See, for example, Insurance Co. v. Brame, 95 U.S. 754, 758 (1877), in which a life insurer was denied recovery from a tortfeasor who killed the insured, because the relationship between the insurance company and the deceased "was created by a contract between them, to which [the tortfeasor] was not a party. The injury inflicted by him was upon [the insured] against his personal rights; that it happened to injure the plaintiff was an incidental circumstance, a remote and indirect result, not necessarily or legitimately resulting from the act of killing." See also Rockingham Mut. Fire Ins. Co. v. Bosher, 39 Me. 253, 257 (1855) (insurer could not maintain action against the defendant for malicious damage to the in- 
context imposed its own limitation on liability, could the plaintiff recover. Thus, if $T P$ committed a battery on $A$ or falsely imprisoned $A$, and $B$ suffered economic loss as a result of the tort, $B$ generally was unable to recover, at least under battery or false imprisonment doctrine. As a legal matter, $B$ could not satisfy the touching requirement of battery or the confinement requirement of false imprisonment, because he had not been touched or confined. As a policy matter, courts regarded $B$ 's loss as too indirect to permit recovery.

In contrast, the common law sometimes allowed $B$ to recover where $B$ and $A$ were family members or master and servant. These cases illustrate the courts' willingness to allow economic loss recovery where a self-limiting feature such as a special relationship can be exploited. Families are only so large, and the courts further limited recovery to spousal and parental relationships. ${ }^{88} \mathrm{~A}$ master's suit for injury to a servant likewise could not be taken as precedent for recovery of contractual loss resulting from a tort on another person, because the master-servant relationship originally was one of status similar to a family relationship and not one of contract. ${ }^{67}$ Indeed, the master-servant rule was not extended to all employment cases, ${ }^{68}$ and when the attributes of special status disappeared from the master-servant relation, the cause of action vanished as well. ${ }^{60}$

sured's property because the insurer was too "remotely prejudiced" by the damage); Anthony v. Slaid, 52 Mass. (11 Met.) 290, 291 (1846) (plaintiff who contracted to support town paupers could not recover for extra expense resulting from injury inflicted by the defendant on a pauper, because the injury was too remote and indirect).

co At common law, a husband could recover damages for loss of consortium resulting from torts committed against his wife, and a parent could recover for loss of services when a minor child was injured. More recent cases have allowed a wife to recover relational damages when her husband is injured. See generally W. Prosser, supra note 2, § 125, at 888-90. Although a child traditionally could not recover for relational loss resulting from injury to a parent, the Michigan Supreme Court recently upheld such recovery. Berger v. Weber, 411 Mich. 1, 303 N.W.2d 424 (1981).

67 The servant was obliged to provide personal service, and the master was obliged to care for the servant. The relationship was so personal that the courts allowed the master to recover for torts injuring the servant. See W. Prosser, supra note 2, § 125, at 888; Note, supra note 6 , at 1513-14.

as Carpenter, supra note 13, at 731.

- See, e.g., Myrurgia Perfumes, Inc. v. American Airlines, Inc., 68 Misc. 2d 712, 713, 327 N.Y.S.2d 861, 862 (N.Y. Civ. Ct. 1971) (the theory may have been justifiable "in the early days of the crafts in England, when a servant lived almost as a member of the master's household and was maintained by the master. It is an absurdity in today's urban world."). See also Hartridge v. State Farm Mut. Auto. Ins. Co., 86 Wis. 2d 1, 12, 271 N.W.2d 598, 601 (1978) (recognizing that recovery by the master for injuries to the servant may have been 
In cases of tortious damage to property subject to a contract of sale, the common law exploited title both to extend and to limit recovery. Thus, where $A$ had a contract to sell goods to $B, B$ generally received title and a right to possession even though $A$ retained possession of the goods. ${ }^{70}$ If $T P$ then converted or tortiously damaged or destroyed the goods, $B$ could recover from TP for trespass or conversion. ${ }^{71}$ These torts, however, were directed at the goods, not at the contract, and standing to sue followed title. These restrictions assured a narrow class of potential claimants and limited liability to the value of the property.

The difficulties of keeping liability within appropriate bounds in cases of pure economic loss are compounded because most such cases result not from some physical act creating physical injury, but from words of description or persuasion. Words are not subject to friction and gravity in the same degree as physical acts. They easily spread beyond the initial communication, affecting persons unknown and unknowable to the speaker. These factors make it difficult to construct sensible limits on liability in cases of pure economic loss, yet the need for limits is acute when tortious behavior consists of utterances, because society places a high value on free speech. To the extent that uncertain or overbroad liability causes a speaker to take precautionary steps to avoid liability, the establishment of some limits is imperative. ${ }^{72}$

The need to limit liability in torts involving utterances may explain why intentional torts such as fraud are structured more rigidly than torts involving physical acts and physical injury. Under early landmark cases, liability for fraud was limited to misrepresentations made knowingly or in reckless disregard of the truth, and with intent to mislead; ${ }^{73}$ in addition, only those whom

valid in feudal societies when the relationship was "quasi-familial," but concluding that such recovery no longer is justified in "present day employer-employee relationships").

${ }^{20}$ See, e.g., Grange Co. v. McCabe, 26 Cal. App. 2d 597, 599-600, 80 P.2d 135, 136 (1938); Coburn v. Drown, 114 Vt. 158, 161, 40 A.2d 528, 530 (1945).

${ }^{71}$ See, e.g., Grange Co. v. McCabe, 26 Cal. App. 2d 597, 601, 80 P.2d 135, 137 (1938) (conversion); Kimball v. Harman, 34 Md. 407, 412 (1871) (trover or trespass); Coburn v. Drown, 114 Vt. 158, 162, 40 A.2d 528, 530 (1945) (trover).

72 The Supreme Court recognized this as a matter of first amendment jurisprudence in New York Times Co. v. Sullivan, 376 U.S. 254, 279-80 (1964), when it required proof of actual malice in defamation cases involving public figures. The requirement was based in part on the idea that precautions by publishers to avoid mistaken liability under a more onerous rule would discourage socially beneficial speech.

${ }^{73}$ Derry v. Peek, 14 App. Cas. 337, 350 (1889) (Lord Bramwell); id. at 374 (Lord Herschell); see also W. Prosser, supra note 2, § 107, at 710. 
the defendant intended to deceive could recover. ${ }^{74}$ These early cases built limitations restricting the scope of liability to the defendant's intent into the elements of the tort. More recent authorities, while liberalizing these restrictions, have continued to limit liability comparably. ${ }^{75}$

Fraud, however, is an ill-suited vehicle for extending liability to some contractually based losses while retaining some limits on the scope of liability. The fact pattern of Rice v. Manley ${ }^{78}$ illustrates the problem. In Rice, the plaintiff agreed to purchase cheese for future delivery from Stebbins. The defendant fraudulently sent a telegram to Stebbins, purporting to be from the plaintiff, cancelling the contract; the defendant subsequently purchased the cheese himself. ${ }^{27}$ These facts do not fit comfortably into the elements of fraud: no statement was made to the plaintiff, nor did he rely on any statement to his detriment. Nor did the facts give Stebbins an action, for he suffered no loss as long as the price the defendant paid was as much as the price the plaintiff had agreed to pay. To be sure, the plaintiff could recover damages for breach of contract from Stebbins, and Stebbins could seek indemnity from the defendant, but the circuity of these actions seems wasteful at best. The court in Rice managed to create a direct cause of action for the plaintiff by holding that "indirect" injury resulting from fraud is actionable. ${ }^{78}$ This rationale, however, fails to distinguish the plaintiff's loss from that suffered by other persons dependent on the

74 Peek v. Gurney, 6 L.R.-E. \& I. App. 377, 399-400 (1873).

${ }^{76}$ Thus, even though the Restatement (Second) extends liability to certain negligent misrepresentations, the drafters restricted liability to those persons directly involved in the transaction whom the speaker intended to influence. RESTATEMENT (SECOND) OF TORTS § 552 (1979). The drafters also noted explicitly that the courts have imposed liability for pecuniary loss more cautiously than for physical harm, "because of the extent to which misinformation may be, and may be expected to be, circulated, and the magnitude of the losses which may follow from reliance upon it." Id. § 552 comment a. With respect to intentional fraud, the Restatement (Second) also has extended recovery to persons other than the individual to whom the statement is made, but only where the maker of the statement "intends or has reason to expect that [the statement's] terms will be repeated or its substance communicated to the other," and that the other will rely upon it. Id. $\S 533$.

Even with these extensions of liability, the intent, purpose, and expectations of the statement's maker still serve as liability-limiting devices. The plaintiff still must rely on the statements made, and the defendant still must expect that such reliance will occur.

${ }^{78} 66$ N.Y. 82 (1876).

77 Id. at 83-84.

78 Id. at 87 ("The mere forms adopted for the perpetration of frauds are of little importance; it matters not whether the false representations be made to the party injured or to a third party, whose conduct is thus influenced to produce the injury, or whether it be direct or indirect in its consequences."). 
plaintiff's possession of the cheese. ${ }^{79}$

2. Advantages of the Interference Tort as a Liability-Limiting Device. Faced with this state of the world, it is not surprising that courts intent on bringing some cases of contractually based loss within the scope of liability for tortious acts might devise a cause of action separate from traditional torts that at once would create and limit liability. The interference tort is such a cause of action. By requiring the plaintiff to show intent by the defendant to interfere with a particular contract, the tort distinguishes the plaintiff's loss from injuries resulting more indirectly from the defendant's act. ${ }^{80}$

The advantage of the interference tort is illustrated by the following hypothetical. Suppose on the evening Johanna Wagner was to sing for Lumley, Gye kidnapped her, preventing the performance. Wagner would have a straightforward false imprisonment suit for damages, including compensation for the missed performance, but Lumley, if he sought compensation for profits lost due to the cancellation, could not sue Wagner for breach of contract, because her failure would be excused by the doctrine of impossibility. ${ }^{81}$ Any recovery would have to come from Gye or, in modern times, from Lumley's insurance company. ${ }^{82}$ If the court announced a general doctrine making Gye liable to Lumley on the basis of the tort committed against Wagner, Lumley's loss would not easily be

70 See Hales v. Ashland Oil Co., 342 So. 2d 984, 986 (Fla. Dist. Ct. App. 1977). There appears to be no subsequent development of the "indirect injury" test for fraud, perhaps because similar cases now are viewed as intentional interferences with contracts. Defamation and trade disparagement cases mirror the fact pattern in Rice in that the defendant makes a false statement to a third person that causes the plaintiff's loss. In these cases, however, because the false utterances refer directly to the plaintiff or his products, the common law could limit recovery to the person defamed or disparaged without extending liability to other persons who were in some way injured. See generally W. Prosser, supra note $2, \S 111$, at 749 .

${ }^{80}$ In Hales v. Ashland Oil Co., 342 So. 2d 984, 986 (Fla. Dist. Ct. App. 1977), the defendant defrauded Pickard, depriving him of supplies he needed to perform contracts with the plaintiff and others. The plaintiff sued the defendant for contract interference, but the court denied recovery because there was no evidence that the defendant's behavior focused on the plaintiff's contract. This failure of proof made the plaintiff's loss too "indirect." See also J'Aire Corp. v. Gregory, 24 Cal. 3d 799, 804, 598 P.2d 60, 63, 157 Cal. Rptr. 407, 410 (1979), a case of negligently caused economic loss where the court imposed liability because the act of the defendant "was intended to, and did, directly affect" the plaintiff.

s1 See Autry v. Republic Prods., Inc., 30 Cal. 2d 144, 180 P.2d 888 (1947) (en banc) (actor drafted into armed forces excused from performance).

82 A contemporary example is the National Broadcasting Company's insurance with Lloyd's of London covering its frustrated contract to televise the boycotted 1980 Olympics. See N.Y. Times, Jan. 21, 1980, at A6, col. 3. 
distinguishable from the economic loss of others who relied on the performance-for instance, concessionnaires, taxi drivers, and nearby restaurants. On the other hand, if a plaintiff suffering economic loss is required to show that Gye knew of his contract or expectancy and purposely disrupted it, the number of successful plaintiffs and the extent of liability are considerably smaller.

On the other hand, adopting new terminology or a new tort creates the potential for unwittingly undermining the policies of traditional tort rules. In a jurisdiction that makes any intentional interference actionable subject only to a showing of justification, the plaintiff who suffers contractual injury because of fraud or defamation is far better off than the plaintiff whose injury is more direct. For example, if the defendant's act is defamatory, the plaintiff may have to show special damages and other technical elements of a prima facie case..$^{83}$ In contrast, the plaintiff who claims contract interference need only allege the intent to interfere with the contract, and the burden of explanation then shifts to the defendant. A plaintiff thus has an incentive to allege contract interference in circumstances where he otherwise might proceed under a traditional tort theory. ${ }^{84}$ The problem is exacerbated in malicious prosecution and its civil counterpart, where the plaintiff ordinarily must show that the allegedly wrongful proceedings were terminated in his favor. ${ }^{85}$ This requirement is designed to set the very difficult balance for wrongful use of legal remedies; application of the interference tort may upset the balance. ${ }^{86}$

Recognizing the proper role of the interference tort should

ss See W. Prosser, supra note 2 , § 112, at 754 (special damages requirement in slander actons); id. § 113, at 766-76 (publication and other elements of a prima facie case).

84 See, for example, Downey v. United Weatherproofing, 363 Mo. 852, 859-60, 253 S.W.2d 976, 980-81 (1953), in which the plaintiff contracted with a property owner to install insulation and the defendant subsequently induced the owner to breach by representing that the plaintiff was insolvent and unreliable. The court held that a cause of action for contract interference was alleged, even though the statements were not alleged to be false. Id. at $859,253 \mathrm{~S}$.W.2d at 981 . The court held that unlike in cases of fraud or defamation, the defendant in an interference case has the burden of showing that his interference was "justified." Id. at 859-63, 253 S.W.2d at 980-81. See also Chemawa Country Golf, Inc. v. Wnuk, 402 N.E.2d 1069 (Mass. App. Ct. 1980).

ss See W. Prosser, supra note $2, \S 119$, at 835 ; id. $\S 120$, at 853.

so In Erlandson v. Pullen, 608 P.2d 1169, 1172 (Or. Ct. App. 1980), the court sustained a demurrer to a claim that a civil suit had been wrongfully instituted, because favorable termination was not alleged. On the same facts, however, the court reversed a demurrer on a claim of interference with a business relationship. Id. at 1172. But see Baker Driveaway Co. v. Bankhead Enterprises, Inc., 478 F. Supp. 857, 860 (E.D. Mich. 1979) (count of interference with a business expectancy interpreted as one in malicious prosecution). 
highlight remaining issues too often submerged in interference tort cases: Is the behavior of the defendant detrimental to the interests of society? Should the plaintiff have standing to challenge the lawfulness of the defendant's behavior? Did the plaintiff suffer a loss of a type that should be legally compensated? I do not intend to examine in a comprehensive fashion the circumstances under which liability for tortious acts should be extended to contractually based losses. There are many cases in which such losses intuitively seem to be a proper cost of the defendant's behavior under any theory of tort liability. What is important here is to recognize that use of the general interference tort in unlawful means cases does not help to determine whether any contractual losses should be recoverable, but serves only to distinguish recoverable losses from more indirect losses so that some workable limits on liability may be maintained.

\section{B. Interference by Means Otherwise Lawful}

Where TP's behavior is independently tortious, the application of tort principles to reach tort objectives is at least facially supportable. The Restatement (Second) ${ }^{87}$ and the law of many jurisdictions, ${ }^{88}$ however, extend liability to cases where the defendant's actions are not independently unlawful, rendering such actions tortious solely because the intent, the result, or both were to disrupt a particular contractual relationship. Thus, if $A$ has a contract to buy widgets from $B$ for $\$ 10$, and $T P$ induces $A$ to breach by offering to sell him widgets for $\$ 8$ each, at least a prima facie case of tort liability is made out if it is shown that TP knew of the preexisting contract, even though TP's offer was not otherwise unlawful. $T P$ then has an opportunity to demonstrate that his behavior was justified, but the fact of competition alone is not enough to immunize TP from liability in all circumstances.

It is startling that doctrine of this sort is superimposed on an economic order committed to competition. As one member of the American Law Institute observed in the debate over Dean Prosser's draft on tortious interference for the Restatement (Second),

87 See Restatement (Second) of ToRTs $\$ 766$ comment i (1979).

${ }^{\text {ss }}$ See, e.g., Imperial Ice Co. v. Rossier, 18 Cal. 2d 33, 35, 112 P.2d 631, 632 (1941) (en banc); Wade v. Culp, 107 Ind. App. 503, 513, 23 N.E.2d 615, 619 (1939); Wear-Ever Aluminum, Inc. v. Townecraft Indus., Inc., 75 N.J. Super. 135, 142, 182 A.2d 387, 391 (Ch. Div. 1962); American League Baseball Club of N.Y. v. Pasquel, 187 Misc. 230, 232-33, 63 N.Y.S.2d 537, 538-39 (Sup. Ct. 1946). 
"foreign lawyers reading the Restatement as an original matter would find it astounding that the whole competitive order of American industry is prima facie illegal."89 As another member said, "in a competitive society it should be assumed that competition is a good thing, and that a person need not be placed in the position of defending his status as a competitor when he engages in .. . normal competitive acts."90

Where TP's behavior is otherwise lawful, the justification for tort liability depends on the nature of the disrupted expectancy-an issue governed by contract doctrine. Existing contract doctrine seems designed to promote allocational efficiency by minimizing transaction costs and encouraging nonperformance where efficiency gains result. ${ }^{91}$ In the absence of some unlawful act that independently supports tort liability, the tort liability rule must promote-or at least not interfere with-this efficiency objective if it is to protect contractual stability properly. If anything, however, inducer tort liability interferes with efficiency.

1. Contract Remedies and Efficient Breach Analysis. When $A$ and $B$ form an executory contract, it may be assumed that both expect to gain from the transaction and that it is the best deal available. If there were some more advantageous opportunity at the time of contracting, they presumably would have taken advantage of it. Breach occurs because of changed circumstances that cause one party to regret his promise. A party may acquire new information disclosing a superior opportunity-for instance, a chance to sell to a third party who values the performance more highly than the original contracting parties.

As long as the legal rules regulating breach place the promisee in the same position as if the promisor had performed-as contract remedies purport to do-no party suffers loss from breach, and the net result is social gain as resources are redirected to a more highly valued use. Under a compensatory damage rule, the normal rule of

95 46 ALI Proceedings, supra note 19, at 201 (statement of Professor Carl Auerbach).

so Id. at 196 (statement of Worth Rowley).

-2 R. Posner, Economic Analysis of Law 88-93 (2d ed. 1977); Barton, The Economic Basis of Damages for Breach of Contract, 1 J. Lagal Stud. 277 (1972); Birmingham, Damage Measures and Economic Rationality: The Geometry of Contract Law, 1969 Duke L.J. 49. There appears to be little dispute that efficiency is a significant object of contract remedies, and the Restatement (Second) of Contracts explicitly recognizes this view. RESTATEMENT (SEcond) of ConTracts introductory note to ch. 16, at 2-7 (Tent. Draft No. 14, 1979). There is disagreement, however, on the mix of remedies that best implements the efficiency objective. See note 95 infra. 
contract law, ${ }^{92}$ breach will occur only when the promisor can gain enough from the alternative opportunity to buy out the promisee and have some additional gain left over. ${ }^{93}$ Where contract law awards specific performance, the promisor may have to offer the promisee part of his additional gain from the alternative opportunity to convince him to forgo specific performance. ${ }^{84}$ Under a compensatory damage rule, the promisor keeps the additional gain from the alternative opportunity; with specific performance, the promisor and promisee share that gain. Thus, in the absence of transaction costs, only the distributional result varies with the remedy; the allocational result is the same in both cases.

In the real world, however, transactions have costs, and the choice of remedy can alter the allocational result by creating incentives to engage in inefficient behavior. ${ }^{95}$ In particular, the choice of remedy can affect the parties' incentives to search for alternative opportunities and to cover or salvage when breach occurs.

92 See Holmes, The Path of the Law, 10 Harv. L. REv. 457, 462 (1897) (common law normally did not compel performance, but only required a breaching party to provide compensation for nonperformance).

${ }^{93}$ If $A$ agrees to sell widgets to $B$ for $\$ 10$ (the market price) and subsequently can redirect his resources to sell gidgets to $T P$ for $\$ 15, A$ captures the $\$ 5$ gain on the gidgets for himself. If the market price for widgets remains $\$ 10, B$ can seek the equivalent of performance in the market and no compensatory damages will be awarded beyond incidental damage. Or $A$ can purchase widgets in the market to satisfy his contract with $B$ and still make gidgets for $T P$. In either case, the allocational and distributional results are the same.

* Assuming a contract and market price of $\$ 10$ and an alternative opportunity worth $\$ 15$, if $A$ offers $B \$ 13$ to waive his right to specific performance, both parties gain by not performing their original contract.

${ }^{\text {gs }}$ Contract scholars are split over what remedial regime is most efficient. The debate centers on whether existing remedies reflect what the parties in most circumstances would select and whether existing remedies adequately compensate the breached-against party. Compare Kronman, Specific Performance, 45 U. CHI. L. REv. 351, 365-69 (1978) (existing availability of specific performance usually efficient) with Schwartz, The Case for Specific Performance, 89 YaLE L.J. 271 (1979) (arguing for more extensive use of specific performance). Compare also Goetz \& Scott, Enforcing Promises: An Examination of the Basis of Contract, 89 YALE L.J. 1261, 1288 (1980) (suggesting that in theory, less than full compensation may be efficient) with Farber, Reassessing the Economic Efficiency of Compensatory Damages for Breach of Contract, 66 VA. L. Rev. 1443, 1468-78 (1980) (arguing for supercompensatory damages for bad faith breaches). See also Linzer, On the Amorality of Contract Remedies-Efficiency, Equity, and the Second Restatement, 81 CoLUM. L. REv. 111, 131-34 (1981) (advocating a case-by-case approach for determining when specific performance should be decreed). Resolving this debate is beyond the scope of this article, particularly to the extent that the issue is normative. The more limited objective here is to understand the incentive structure of contract remedies to determine to what extent the interference tort promotes or interferes with that structure. With this objective in mind, the important point is that all the authors accept efficiency as a significant objective, and they seem to accept it as a powerful explanatory tool in understanding existing contract remedies. 
A party will search for superior opportunities only as long as his expected gain exceeds his costs; to the extent that remedies for breach deprive him of gains from breach, his willingness to search diminishes. As between contracting parties, giving one party the gains increases that party's incentive to search but decreases the other party's incentive. One explanation of the existing mix of damage and specific performance remedies in contract law is that it gives the gains to the party likely to be the cheaper searcher. Where an active market exists for the subject matter of the contract, the prevailing damages rule promotes efficiency by giving the seller the whole benefit of any gain, because the seller is likely to be the cheaper searcher. In active markets, the likelihood of discovering a party who will pay more than market price is small,;8 the most likely source of gain is in finding an alternative use for the resources required to produce the subject matter of the contract. In a sales contract, for example, the manufacturer of a market-priced widget may gain by devoting his resources to some other product. Ordinarily the seller is better situated to search for and to evaluate alternative production opportunities. As owner of the resources, he is likely to know best what alternative uses they can serve and at what cost. ${ }^{97}$ On the other hand, where the subject matter of the contract is unique, opportunities are likely to be evaluated as easily by the promisee as by the promisor. ${ }^{98}$ Authorizing specific performance, which forces the original parties to share the gains from breach, seems consistent in a rough way with a shared ability to search. ${ }^{99}$

\footnotetext{
'6 If there is a market price, the only opportunity for price gain is to find someone with idiosyncratic tastes who is willing to pay more than the market price.

${ }^{27}$ In the case of active markets, search incentives will not be influenced strongly by the remedy for breach, because a promisor facing a punitive remedy for breach can cover with goods obtained on the market, thereby avoiding the legal sanction.

s8 With unique goods, search is more likely to disclose a more advantageous opportunity than with fungible goods. Kronman, supra note 95, at 368 , argues to the contrary, but on this point he seems clearly wrong. See Schwartz, supra note 95, at 280-81.

"2 Application of specific performance in a sales contract is reciprocal. The seller in unique goods cases may sue for the purchase price. U.C.C. \& 2-709(1)(b) (1978). Schwartz, supra note 95, at 283-84, argues that because promisors (sellers) of a unique good are more likely to find a better price through search, they will prefer damages to specific performance. Promisees, Schwartz argues, may prefer specific performance unless they think they could make an exaggerated damage claim successfully. Fashioning a legal rule that reflects what most parties would agree to would require knowing whether promisees' expected gains from specific performance outweighed promisors' expected damages. Absent a strong intuition on this point, adoption of specific performance as the legal remedy gives the parties the option of negotiating a compensatory damage remedy, whereas a damage rule does not allow alteration by private agreement, because the common law normally refuses to enforce agreements
} 
Once breach occurs, contract remedies also seem to encourage the party who can procure substitute performance at the least cost to do so. A compensatory damage rule places the onus of seeking alternative performance on the promisee: for example, if a seller breaches and is required only to pay compensatory damages, the buyer must purchase substitute goods. If specific performance is awarded, the seller who finds a better use for the subject matter of the contract is encouraged to purchase substitute goods on the market to avoid sharing his gains from the better use with the original buyer. With market-traded goods, the prevailing damages rule seems efficient because buyers presumably are better able to buy than sellers. ${ }^{100}$ With unique goods, no perfect substitute is available and neither party has an apparent advantage in finding substitute goods. ${ }^{101}$ Forcing a bargain by use of a specific performance remedy thus seems consistent with efficiency.

Assuming that the parties negotiated before breach regarding their right to search and duty to cover, they probably would establish a regime that exploited any advantage one had over the other. ${ }^{102}$ By prescribing such a regime as a matter of law, contract doctrine saves the costs of these negotiations.

2. Inducer Liability and Efficient Breach Analysis. Whereas a tort often signals social loss, breach of contract signals the potential for social gain. If allocational efficiency is the objective of con-

calling for specific performance. Where the selection of the legal remedy depends on an uncertain intuition, giving the parties freedom to bargain out of the imposed rule increases the chance that they will choose the optimal rule. For a discussion of analogous punitive liquidated damage provisions, see generally Goetz \& Scott, Liquidated Damages, Penalties and the Just Compensation Principle: Some Notes on an Enforcement Model and a Theory of Efficient Breach, 77 CoLum. L. Rev. 554 (1977).

Unquestionably, the costs of enforcing specific performance in cases such as employment contracts and the costs of determining compensatory damages accurately in unique goods cases are important factors in the current array of remedies. But even if the remedial landscape is not determined by its effect on search behavior, that landscape still seems consistent with reducing the costs of search.

${ }^{100}$ Schwartz, supra note 95 , at $286-88$, rejects the hypothesis that buyers generally have lower cover costs than sellers and thus argues that a damage rule for nonunique goods does not necessarily reduce negotiation costs. Of course, the analysis must be at the margin, and although some sellers may be in a relatively better position to cover, it seems at least plausible that more often than not, the reverse is true.

${ }^{101}$ In markets such as the antique market, sellers may be better able to locate close substitutes. On the other hand, the buyer is better able to judge the value of the offered substitute.

${ }^{102}$ For purposes of this analysis, it is not necessary to determine if either factor-search or cover-is more important, because the imposition of liability on a third-party inducer conflicts with both objectives. 
tract law, legal rules should encourage persons to search for and to take advantage of more highly valued uses for resources under their command. In efficiency terms, there is no reason why formation of one contract should bring the process to a halt or prevent third parties from inducing nonperformance of inefficient contracts. Contract rules seem designed to facilitate breach where efficiency gains result; the inducer liability rule, in contrast, seems designed to reduce the number of such breaches and thus runs counter to a plausible objective of contract doctrine.

In analyzing the effect of an inducer liability rule, I first adopt two counter-factual assumptions: first, that if the inducer is liable for contract disruption, his liability to the promisee is the same as the breaching promisor's liability-that is, that the measure of damages would be the contract measure; and second, that the inducer, if potentially liable, is free to shift his liability by contract to another party, presumably the breaching promisor. These assumptions isolate the effect of liability per se. In reality, the law imposes a more onerous measure of damages on the inducer and restricts his ability to contract out of liability, ${ }^{103}$ making the case against inducer liability even stronger.

With or without tort liability, a third-party inducer will search for advantageous opportunities as long as the search and transaction costs of doing so do not exceed the expected gain. As long as the measure of damages is the contract measure, ${ }^{104}$ inducer tort liability does not affect the third party's expected gain. To the extent the gain must be derived from the disruption of an existing contract, the third party will be forced to negotiate with one of the contracting parties. If he negotiates with the promisee, he will be forced to offer the promisee some gain over the promisee's expected gain from the original contract. If he negotiates with the promisor, he will be forced to offer the promisor some gain over the compensatory damages the promisor will be forced to pay the promisee for breach. The promisee's expectancy thus limits the gain likely to be derived by search; this is so whether the inducer is forced to pay the promisee compensatory damages or to account to the promisee through negotiations. In this respect, holding the inducer liable in tort rather than holding the promisor liable in contract does not seem to interfere with the efficient allocation of the

${ }^{203}$ See text and notes at notes 118-126 infra.

104 Because the true tort damage measure may be higher, inducer tort liability actually may lower the expected gain from search. See text and notes at notes 119-123 infra. 
promisor's performance or the likely level of search by the thirdparty inducer.

The level of search, however, depends not only on the expected gain, but on transaction costs, and inducer tort liability increases these costs. If the third party initially offers the alternative opportunity to the promisor, the negotiations must account for the liability to the promisee. In the absence of tort liability, the promisor could retain the portion of the gain from the alternative opportunity necessary to compensate the promisee. Because the third-party inducer may be liable along with the promisor, however, the parties must guess to whom the promisee will look for compensation. If they guess wrongly, an additional transaction is required to shift the loss back to the party who agreed to bear it. Thus, if the gain from the alternative opportunity is $\$ 100$ and the promisee's expectancy is $\$ 25$, the third-party inducer and the promisor will bargain over the distribution of the $\$ 75$ gain. One of them must hold the $\$ 25$ in reserve to pay the promisee. In many cases, the promisee will be bought out directly, but if not, the promisor and the inducer must agree that one will hold the reserve and indemnify the other if the other is called upon to pay. The costs of the indemnity transaction arise solely from the tort liability imposed on the third-party inducer and would be eliminated in the absence of liability. ${ }^{105}$

Tort liability also impairs the inducer's ability to negotiate with the party better able to take advantage of the alternative opportunity. To the extent anything systematic can be said about promisors' and promisees' relative abilities to exploit alternative advantages, promisors tend to have the advantage where goods are traded actively. For unique goods, the advantage may be distributed randomly among promisors and promisees. Accordingly, inducers probably will want to deal with promisors in active markets, and in unique goods cases, the context will be determinative. An inducer free of personal liability will be free to deal with the better party. Tort liability undermines this freedom by encouraging the inducer to negotiate with the promisee to avoid the possibility of litigation. ${ }^{108}$ To the extent an inducer liability rule forces the in-

${ }^{105}$ In fact, the parties may not be able to make an enforceable indemnity agreement at any cost, because contracts depending on breach of another contract are unenforceable. See text and note at note 120 infra.

${ }^{108}$ Ordinarily the risk of litigation is subject to some control by the party forced to bear it. Under the analysis in text, however, the inducer and promisor run the risk of indemnity and accordingly assume responsibility for the other's poor management of that risk. The 
ducer to consider factors other than which of the original contracting parties can maximize the gain from the alternative opportunity, the rule imposes social costs.

It also is difficult to see how a rule of inducer liability will reduce salvage costs. For an inducer liability rule to reduce cover costs, the inducer must be better able to cover than either the promisor or promisee, but in most instances, the inducer will be no better at this than the promisee. This is because the inducer occupies the same relative position in a transaction as the promisee; that is, where the promisor is a seller, the inducer, like the promisee, will be a buyer. Moreover, the inducer will be less informed than the promisee as to the promisee's requirements. This may make no difference with perfectly fungible goods, but the best possible case is that the promisee and inducer will have equal access to the market; the inducer is unlikely to be a better salvager. Where goods are not perfectly fungible, the promisee alone knows what is an adequate substitute. Even the promisor who has had past dealings with the promisee is more likely to be a cheaper salvager than the third-party inducer. Thus, to the extent an inducer liability rule encourages the inducer to cover, it imposes social costs. ${ }^{107}$

3. Personal Service Contracts and Efficient Breach Analysis. Employment contracts create some unique issues in determining the extent to which tort protection is desirable. For several reasons, traditional contract remedies may seem less satisfactory in employee breach cases than elsewhere. ${ }^{108}$ First, the common law assumed that all employment contracts were terminable at will by either party unless a fixed term was expressed unequivocally. ${ }^{109}$ If no fixed term is expressed, no remedy for breach of contract is available because no breach occurs. Second, contracts with fixed terms are more likely to be used for employees with special skills.

risk of litigation also may entail costs to the inducer not easily monetized in negotiations with the promisor. These considerations give the inducer an incentive to prevent litigation by striking a bargain with the promisee.

${ }^{107}$ In many jurisdictions, the actual tort measure of damages is higher than the contract measure of compensatory damages. See notes 119-123 infra. See also National Merchandising Corp. v. Leyden, 370 Mass. 425, 430-33, 348 N.E.2d 771, 774-76 (1976) (requiring an inducer to disgorge his profits). This has the same effect as specific performance by encouraging the inducer to cover in all cases to avoid the legal sanction, even where another party could cover at less cost.

${ }_{108}$ Employer breach (wrongful discharge) does not seem to raise issues very different from breach of other types of contracts. See note 111 infra.

${ }^{109} 1$ A. CoRBin, supra note $34, \S 96$, at 416-18. 
In such cases, the standard contract damage measure-contract price-market price differential-is largely unavailable because there are few active markets for unique employees. Furthermore, personal service contracts, like all best-efforts contracts, are diffcult and expensive to police; thus, specific performance generally is denied. ${ }^{110}$ These difficulties are largely avoided by holding a thirdparty inducer liable in tort. Notwithstanding these difficulties, existing contract remedies for an employee's breach of an employment contract seem consistent with efficient breach theory, ${ }^{111}$ and the same social costs may be incurred as in other contexts if the interference tort is applied too widely.

When an employee breaches, the prevailing damage rule allows the employer to recover the difference between the contract price and the cost of securing an adequate substitute. ${ }^{112}$ Where the employee's skills are not unique, the cost of substitution is probably reflected in a market wage. The effect of the damage rule therefore is to allow the breaching employee to secure the entire gain from his breach and to place the burden of securing substitute employees on the employer. If there is a market wage for the skills used in the first employment, gains will be forthcoming from breach only if the employee can find subsequent employment utilizing different, more highly valued skills. The costs of finding such an opportunity are likely to be less for the employee, who knows what additional skills he possesses. Likewise, the original employer, as a purchaser of labor, is likely to be better situated to secure substitute employees.

Where the employee possesses some unique skill, as in the case of an entertainer, professional athlete, or high-ranking executive, he is less likely to have a search cost advantage. ${ }^{113}$ The em-

210 D. DobBs, HandBook on the Law of Remedies § 12.26, at 933 (1973).

111 Remedies for employer breach (wrongful discharge) are also consistent with efficient breach theory. The employee generally is entitled to compensatory damages, that is, his contract price reduced by income obtained or reasonably available from alternative employment. Id. $\$ 12.25$, at 924-25. The absence of external markets in many employment contexts requires the courts to use a surrogate for market price, but the mitigation principle seems to be an adequate substitute. Courts have uniformly refused specific performance ordering the employee reinstated. $I d$. at 929-30. Given monitoring costs and the few instances in which a job would be unique, the absence of equitable relief is warranted and consistent with efficient breach theory.

${ }^{112}$ Id. § 12.26, at 932 .

113 Whether the employer or employee has the relative advantage depends on the context. In professional athletics, the employer is allowed to search out employers (other teams) who value the employee more highly and to receive direct compensation for the "sale," but because an employee is not a material object, the employer cannot sell an employee outright 
ployer is also less likely to have an advantage in finding a substitute employee. ${ }^{114}$ Contract law, in analogous sales cases involving unique goods, grants specific performance, forcing the parties to negotiate over the division of gains from breach and the responsibility for procuring substitute performance. This may be seen as a recognition of the inability to assume that either party has a search or salvage advantage. Because specific performance of employment contracts involves significant enforcement costs, courts generally deny specific performance; however, they have developed remedies which for practical purposes reach the same result as specific performance at less cost. Courts will enforce express agreements prohibiting an employee from working for a competitor if the restriction is reasonable as to time and place. ${ }^{115}$ Enforcement of such clauses does not involve significant monitoring costs, yet provides an incentive for the employee to bargain with his original employer for a release. In fashioning a damage remedy for employee breach cases, some courts have adopted what amounts to a rebuttable presumption that the wage received by the employee in his subsequent employment is the market price of a substitute employee. ${ }^{116}$ This presumption provides the same incentive to bargain as specific performance, because it gives the original employer the initial entitlement to all gains from breach. ${ }^{117}$

in most other circumstances. Thus he will have little incentive to search out more advantageous employment for his employees. On the other hand, a business profits from its employees' skills, so that employers are in the business of searching for opportunities to apply these skills in the marketplace. The employer is likely to know the extent of the employee's skills, and it is likely that the skill the employer exploits is the one for which the most advantageous opportunities exist.

${ }^{114}$ Skilled employees are as likely as the original employer to know other persons possessed of the same skills. Employers generally must deal with a wide variety of skilled employees, whereas professional journals and associations tend to divide by skill, bringing persons of similar skills together.

${ }_{116}$ See Reed, Roberts Assocs., Inc., v. Strauman, 40 N.Y.2d 303, 307, 353 N.E.2d 590, 592-93, 386 N.Y.S.2d 677, 679 (1976).

110 Roth v. Speck, 126 A.2d 153, 156 (D.C. 1956); Rooney v. Weeks, 290 Mass. 18, 29-30, 194 N.E. 666, 671 (1935); Triangle Waist Co. v. Todd, 223 N.Y. 27, 30-31, 119 N.E. 85, 86 (1918). See also Annot., 61 A.L.R.2d 1008 (1958).

112 The presumption is rebuttable by proof that the subsequent employment is signifcantly different-that it requires different skills than the original employment. This result is consistent with the analysis of sales cases. The employer may have at least an equal advantage in searching for better opportunities for the unique skills of the employee for which he originally contracted. See note 113 supra. To the extent the employee seeks to market those skills elsewhere, he must buy out his original employer. On the other hand, the employee is likely to have a relative advantage in marketing different skills, and the presumption works in a rough way to encourage cost-minimizing search by the employee. 
4. Peripheral Rules-Tort Damages and Contracting Out. Inducer tort liability in both sales and employee breach cases creates inefficient negotiation, search, and salvage incentives and increases transaction costs. ${ }^{118}$ These social costs are increased by two legal rules that interfere still further with allocational efficiency. First, because the cause of action against the inducer is in tort, most courts have imposed a tort measure of recovery, allowing the promisee to recover damages for pain and suffering in addition to the value of the lost performance. ${ }^{119}$ Second, contracts involving the breach of another contract are unenforceable. ${ }^{120}$

The tort measure of damages changes the efficiency equation in interference cases. The gain from breach must be greater not only than the value of performance, but also than the enhanced tort damages. The inducer's incentive to search for a more advantageous opportunity is reduced accordingly, and some otherwise efficient reallocations of resources will not occur. To this extent, an allocational loss occurs and social welfare suffers. In those instances where search continues, the existence of an enhanced damages measure makes it more likely that the promisee will sue the inducer rather than the promisor. In one sense, this provides greater certainty to negotiations between the inducer and promisor regarding the location of the reserve to pay the promisee. ${ }^{121}$ This also gives the inducer an incentive to deal with the promisee, however, even though the promisor may be the party better able to take advantage of the opportunity. ${ }^{122}$ The enhanced measure also encourages the inducer to try to salvage the contract when it seems plausible that he is the party least able to salvage at a reasonable cost. ${ }^{123}$

It might be argued that the tort damage measure comes closer to compensating the promisee in full and therefore is preferable to the contract measure, for it is widely recognized that contract rem-

118 See text and notes at notes 105-107 supra.

11 See Restatement (Second) of Torts § 774A (1979). But see Armendariz v. Mora, 553 S.W.2d 400, 406 (Tex. Civ. App. 1977) (contract measure of damages applied, with breacher and inducer jointly and severally liable).

120 RESTATEMENT OF ConTRACTS \& 576 (1932) ("A bargain, the making or performance of which involves breach of a contract with a third person, is illegal."). There is, on the other hand, ample evidence that inducers and breachers do enter into such agreements. See, e.g., Engine Specialties, Inc. v. Bombardier, Ltd., 605 F.2d 1, 4-5 (1st Cir. 1979) (inducer agreed to indemnify breacher for damages paid to promisee), cert. denied, 446 U.S. 983 (1980).

121 See text and note at note 105 supra.

${ }^{122}$ See text and note at note 106 supra.

${ }^{123}$ See text and note at note 107 supra. 
edies may be undercompensatory - that is, that promisees are not indifferent as to breach. Attorney's fees are one category of costs associated with breach for which recovery generally is denied. If undercompensation occurs, however, it occurs for all breaches, not just those induced by a third party. To the extent that undercompensation interferes with the objectives of contract doctrine, a reform applicable to all breaches seems a more appropriate response. ${ }^{124}$

Courts' unwillingness to enforce agreements that contemplate breach of another contract is also inconsistent with efficient breach, because it prevents inducers and breachers from allocating the gains and liabilities from the breach. Neither promisor nor inducer can know in advance of a lawsuit to whom the promisee will look for the value of the performance. ${ }^{125}$ Under present law, there appears to be no enforceable way the promisor and inducer can agree to reallocate the payment once that choice is made by the promisee. Some efficient breaches therefore will not occur, because there is no assurance that liability and the gains from breach will be allocated to the same party. ${ }^{126}$

5. Interference with Unenforceable Expectancies and Prospective Relationships. Efficient breach analysis also applies where a third party interferes with a mere expectancy not embodied in an enforceable contract. In these cases, the promisee either recovers from the third party or remains uncompensated. Contracts that are void, voidable, or unenforceable by operation of law; contracts that are expressly terminable at will; and relationships that are merely prospective because the parties have not reached an agreement are all illustrative of this situation.

Efficient breach analysis suggests that as long as the relationship maximizes both parties' expected gains, the relationship will continue and eventually will result in the capture of these prospec-

124 Schwartz, supra note 95, argues that a damage rule systematically undercompensates and thus, that a specific performance rule of broader applicability is preferred. See also Farber, supra note 95, at 1468-78, arguing for supercompensatory damages for bad faith breaches. Compare Goetz \& Scott, supra note 95, at 1288, where it is argued that undercompensation may be efficient.

125 See text and note at note 105 supra.

126 The refusal to enforce these agreements may appear consistent with the rule against contribution between joint tortfeasors. To the extent the behavior underlying the interference is independently tortious, the analogy is strong, and there is an argument that the nocontribution rule is efficient. See Landes \& Posner, Joint and Multiple Tortfeasors: An Economic Analysis, 9 J. Legal Stud. 517, 552-55 app. II (1980). The analogy breaks down, however, for cases of interference resulting from lawful means. 
tive gains. Only when some more advantageous opportunity arises will a party sever or avoid the relationship. To the extent society is better off when parties seek more advantageous relationships, avoidance of inefficient relationships is as desirable as breach of inefficient contracts. An inducer liability rule would give rise to the same undesirable search and salvage incentives in prospective relationships and unenforceable expectancies as exist in enforceable contracts, ${ }^{127}$ and such a rule would also lead to the same inefficient results.

Rules regulating third-party interference should advance whatever policy contract law pursues in withholding enforcement of an agreement. If contract doctrine allows a contracting party to avoid an agreement when that party discovers a better deal, it should not matter that the information about the better deal is provided by a third party. Liability for lawful third-party behavior implicates actions ranging from disinterested advice that the contract is unenforceable to a specific inducement offering better terms. ${ }^{128}$ Although liability for interfering with a prospective contract by fraud, violence, or other unlawful acts may be justified by a desire to discourage these forms of behavior, it is difficult to construct an affirmative reason for protecting expectancies from otherwise lawful behavior. ${ }^{129}$ If the efficiency principles of contract law

${ }^{127}$ See text and notes at notes 96-105 supra.

${ }_{128}$ The Restatement (Second) formulates a privilege to give "truthful information" or "honest advice within the scope of a request for the advice." RESTATEMENT (SECOND) of ToRTs $\$ 772$ (1979). Presumably a lawyer advising a client that he need not perform a contract because of the statute of frauds could assert this privilege. The commentary also suggests that advice from an amateur is permitted as long as it is requested, even if the person giving the advice profits from it. Id. $\S \mathbf{7 7 2}$ comment $c$. Truthful information may be given at any time regardless of a request. Id. comment $b$. The lines between truthful information, advice, and improper inducement, however, are far from clear. May a third person announce truthful information that a contract is unenforceable and then offer better terms? Or may he solicit a request for advice? If either of these two approaches is privileged, but direct encouragement to breach is improper, form has triumphed over substance. See Sweeley v. Gordon, 47 Cal. App. 2d 387, 387, 118 P.2d 842, 842, denying rehearing to 47 Cal. App. 2d 381,118 P.2d 16 (1941), in which a buyer was held not liable for inducing the seller of real estate to assert the invalidity of a contractual obligation to pay a broker a commission.

${ }^{129}$ It might be argued that the consideration exacted for a voidable contract reflects the risk that the promisor will exercise his power to avoid, but not the risk of third-party inducements. For example, the seller of nonnecessary goods to a minor may consider the risk of dealing with the minor, who is known to him, but could not take into account the universe of third parties willing to induce the minor to avoid the contract. In the absence of unlawful means such as duress, force, or fraud, however, the fact of third-party intervention seems to add little to the other variables in deciding with whom to engage in voidable contractual relationships. The ultimate decision to avoid remains with the party to the contract, and his willingness to avoid is a risk the promisee takes, regardless of the manner in 
suggest that a third party using lawful means should not be liable for inducing breach of enforceable promises, then a fortiori, the same rule should apply to unenforceable expectancies. ${ }^{130}$

\section{Fairness Concerns}

It can be asserted that neither tort nor contract law is governed by instrumentalist concerns and that the law should achieve justice between the parties, regardless of the social costs of doing so. ${ }^{131}$ Professor Richard Epstein, for example, has proposed a com-

which the promisor comes to exercise his choice. In contracts terminable at will, the bargain is more likely to reflect the risk of termination. Again, as long as unlawful means are not used, it is difficult to see how the risk of third-party inducement is different from other risks the parties assume.

130 Existing case law already may require a showing of unlawful means or motive before subjecting interferences with prospective relationships to tort liability; however, the question is not free from doubt. The Restatement (Second) seems to create a prima facie case of liability for otherwise lawful behavior, requiring an ad hoc balancing of various factors. $R_{E-}$ STATEmENT (SECOND) of ToRTs § 766B (1979). Moreover, when the drafters of the Restatement (Second) wanted to limit liability to cases of unlawful means, they did so in unmistakable language. See $i d$. \& 774B, which requires the plaintiff to show "fraud, duress or other tortious means" when claiming interference with an inheritance or gift. Arguably, the silence of section 766B on this point means that liability is not limited to cases of unlawful means.

On the other hand, the drafters indicate that with respect to prospective relationships, where "the means adopted is [sic] not innately wrongful and it is only the resulting interference that is in question as a basis of liability, the interference is more likely to be found to be not improper." Id. § 766B comment e. Moreover, all the specific justifications for interference, including competition, purport to allow disruption of prospective relationships. See id. $\$ \$ 768-773$. Section 768 specifically allows interference with prospective contractual relations or contracts terminable at will if justified by competition, and comment i notes:

If the third person is free to terminate his contractual relation with the plaintiff when he chooses, there is still a subsisting contract relation; but any interference with it that induces its termination is primarily an interference with the future relation between the parties, and the plaintiff has no legal assurance of them [sic]. As for the future hopes he has no legal right but only an expectancy; and when the contract is terminated by the choice of the third person there is no breach of it. The competitor is therefore free, for his own competitive advantage, to obtain the future benefits for himself by causing the termination.

The New York Court of Appeals recently held by analogy that interference with a contract voidable for lack of mutuality also should be privileged if justified by competition. GuardLife Corp. v. S. Parker Hardware Mfg. Co., 50 N.Y.2d 183, 193-94, 406 N.E.2d 445, 450, 428 N.Y.S.2d 628, 634 (1980).

Many cases of interference with prospective advantages purport to attach liability without isolating an independently unlawful act; however, the facts of these cases suggest unlawful behavior. Many of these cases are considered in part III of this article. Unlawful motive also is used as a justification for liability for disrupting prospective advantages. The problem of attaching liability to motive alone is considered infra part II-D.

131 Professor Dobbs also argues in favor of limiting the scope of the interference tort, but primarily for noneconomic reasons. Although he acknowledges that the tort seems to conflict with the efficient breach hypothesis, he enigmatically concludes that the "efficient 
prehensive corrective justice scheme based on imposing liability for interference with property rights. ${ }^{132}$ If a contract is viewed as a property right, corrective justice principles might be thought at first blush to require liability for interference. The property right in a contract, however, necessarily is defined by the nature and terms of the relationship between the contracting parties. Nothing a third-party inducer might do alters that relationship. No inducer liability is necessary to return the promisee to his status quo ante position, for he still is entitled to compensatory damages or specific performance from the breaching promisor. ${ }^{133}$ Arguably, the prom-

breach point should not be unduly emphasized." Dobbs, supra note 3 , at 361 . Rather, he emphasizes six objections to inducer liability that go to the issue of "justice, or relatedly, to the integrity of the legal system itself." Id. at 344. It seems to me that these noneconomic objections do not strengthen the case against the interference tort significantly.

Professor Dobbs argues first that liability is unjust because it is not based on any principle that explains outcomes. Id. at 346 . This is incorrect. Though flawed, the principle seems to be that a contractual relationship, like a property interest, is protected from unprivileged third-party interference-a principle of sufficient generality but, as principles go, comparable to the one that explains intentional torts directed at physical harm. His second objection is that the use of malice or motive rather than conduct to determine liability "violates the larger terms of law for a free society." Id. at 350. Although I argue that an improper motive standard for liability may be too costly to impose in tortious interference cases, see text and notes at notes 136-156 infra, if a blanket objection to motivation-based liability is offensive to justice, then much of civil and criminal law is similarly suspect. A legal system, even a just one, might conclude that legal incentives to avoid malicious behavior are proper in general but that the costs of error exceed the gains in a particular context. Third, he finds something "very wrong in the state of the law" where two parties by contract can impose a duty on a third party-a result he sees emanating from inducer liability. Id. at 351. On a simple level, however, it is hard to distinguish my act of forming a contract with $X$ from that of driving my automobile down the street. By my presence on the street, I have imposed a duty on other persons to avoid hitting me--a reduction of their freedom. Similarly, an inducer liability rule prevents other persons from contracting with $X$. Dobbs recognizes that the creation of new property interests such as patents or copyrights is analogous to contract formation in that in both cases, one person's activity constrains others' freedom. (The patent prevents others from using the innovation.) He attempts to distinguish patents from contracts on the theory that the "property" in' patents is conferred to encourage creation of new property. Id. at 352-53. This is unconvincing: a contract, like innovation, creates new social wealth by transferring goods or services to a higher use. Dobbs's next two objections are similarly flawed as premises for a noneconomic case against inducer liability. He argues that inducer liability is unjust because it may cause more harm than good, id. at 356-57, and that inducer liability violates an autonomy principle by making one person (the inducer) liable for the voluntary act of another (the breacher), id. at 358-59. The former is a decidedly economic argument; the latter is overbroad and would apply to all forms of vicarious liability. His last objection applies only to interference with personal relationships such as marriage and is not relevant here. Id. at 359.

${ }^{132}$ See Epstein, Intentional Harms, 4 J. LEGAL STUD. 391 (1975), in which the author applies his corrective justice model to intentionally caused economic harm.

${ }^{133}$ Professor Dobbs argues that an interference tort might be justified for specifically enforceable contracts because the contract looks more like a property interest. Dobbs, supra 
isor would have performed in the absence of a third-party inducement, but if contract damages are in fact compensatory, the promisee should be indifferent between performance and damages. If contract damages do not compensate promisees adequately, it seems a far better reform to adjust the damage rule in all breach cases rather than to attempt to reach full compensation only where there is a third-party inducer. ${ }^{134}$

Alternatively, inducer liability might be justified by attaching the stigma of moral reprehensibility to the inducement of breach. ${ }^{135}$ To do so, however, compels a contrast with the legal treatment of the breaching promisor. Contract remedies do not construct incentives to avoid breach; rather, they seem to encourage-or at least to facilitate-it. To hold an inducer liable, his behavior must be at least as culpable as that of the breaching promisor; to impose a liability rule more onerous than that imposed on the promisor, the inducer must be more culpable. It is difficult, however, to isolate a principle of moral philosophy in the context of a mere inducement that would direct as much or more moral derision at a third-party stranger to a relationship than at the promisor who voluntarily made and breached the promise.

note 3 , at 373. Still, he acknowledges the argument that the breached-against party should seek specific performance and not tort recovery from a third party. $I d$. at 373 n.148.

134 It is not clear that Professor Epstein's corrective justice formulation would require inducer liability for lawful acts of inducement or persuasion. Epstein constructs four forms of action that he regards as resulting at least prima facie in liability: force, fraud, compulsion, and dangerous conditions. Only compulsion comes close to describing most cases of inducement by lawful means, and to the extent that compulsion contemplates some overriding of the promisor's ability to act voluntarily, it is usually absent. See Epstein, supra note 132 , at 439 n.124.

1ss An early tradition of contract theory premised promise enforcement in part on the moral obligation to perform. Contemporary expressions of that theory continue to attribute moral culpability to the inducer. See, e.g., Guard-Life Corp. v. S. Parker Hardware Mfg. Corp., 50 N.Y.2d 183, 200, 406 N.E.2d 445, 454, 428 N.Y.S.2d 628, 638 (1980) (Cooke, C.J., dissenting):

If society were interested only in fostering economic competition, the tort of contractual interference would never have developed. Rather, the law would have allowed business entities to engage in unfettered competition, and relegated injured parties to a breach of contract action. But this is not the path that has been followed.

Instead, the law has decided, long ago, that enforcement of certain market morals is a societal interest worthy of protection. When these fundamental precepts are violated, the law provides a remedy.

Absent from such expressions is any more precise explanation of these "fundamental precepts," or how, beyond the instincts of various judges, a code of market morals is to be formulated. 


\section{Propriety of Liability Based on Improper Motive Alone}

The development of the interference tort is connected intimately with the historical debate among common law courts over whether malice can make an otherwise lawful act unlawful. Problems in defining and applying a malice standard caused great confusion in the early English contract interference cases $^{136}$ and may account in some measure for the continuing confusion in more recent cases that led the Restatement (Second) drafters to conclude that the relevance of motive is "closely interwoven with" other factors and may not be "easily separated."137

Malice has been defined in a variety of ways in tortious interference cases. In Lumley $v$. Gye, where malice was announced as an element of the tort, ${ }^{138}$ it was defined as nothing more than notice of a contract's existence. ${ }^{138}$ The result was liability for all intentional interferences. ${ }^{140}$ Subsequently, a malicious act was defined as one with the "indirect purpose of injuring the plaintiff, or of benefiting the defendant at the expense of the plaintiff."141 This definition adds little to one requiring notice, because the only motive it excludes is indifference. Both definitions are broad enough to include socially encouraged acts, including competition. The need to accommodate these social interests resulted eventually in a definition of malice limited to those interferences done with notice and without justification or excuse. ${ }^{142}$ Malice in this form, however, is only an ultimate conclusion reached after balancing the parties' interests; it provides no independent justification for liability, but is merely a recognition of liability. In contrast to these legal definitions, malice in common understanding connotes spite or personal ill will. ${ }^{143}$ This latter form of malice, sometimes referred to as pure malice, became significant in tortious interference cases.

${ }^{138}$ The early English cases are reviewed in Freund, Malice and Unlawful Interference, 11 HaRv. L. Rev. 449, 451-455 (1898).

1s7 See Restatement (Second) of Torts $§ 767(b)$ comment d (1979).

138 El. \& Bl. 216, 224, 118 Eng. Rep. 749, 752 (Q.B. 1853).

139 Justice Holmes described this form of malice as follows: "If the manifest probability of harm is very great, and the harm follows, we say that it is done maliciously or intentionally . . ." Holmes, Privilege, Malice, and Intent, 8 Harv. L. REv. 1, 1 (1894).

140 The breadth of the rule announced in Lumley $v$. Gye may be attributable to the developing idea that a contract created a property right enforceable against the world. Note, supra note 6 , at 1522-28. Thus, in a formalistic approach comparable to trespass to land, any intentional interference was actionable.

141 Bowen v. Hall, 6 Q.B.D. 333, 338 (1881).

142 See W. Prosser, supra note 2, § 129, at 928.

143 See Webster's Third New InTERnational Dictionary 1367 (1976). 
The problem arises because some acts outwardly indistinguishable from competition actually may be anticompetitive and may not produce the long-run social benefits associated with competition. ${ }^{144}$ For example, reducing prices below those of a competitor is ordinarily competitive, but price cutting is anticompetitive if undertaken to secure a monopoly. In theory, these anticompetitive acts can be isolated from socially beneficial acts by proof of improper motive. ${ }^{145}$ Proof of motivation, however, is error-prone and carries social costs. ${ }^{146}$ In addition, pure malice is not a perfect predictor of anticompetitive effect, because an actor motivated by pure malice may choose competitive means to accomplish his purpose: if $T P$ hates $B$ for personal reasons and spitefully searches for a more advantageous opportunity for $A$ so as to interfere with $B$ 's contract with $A$, he nonetheless may produce a social benefit. ${ }^{147}$

${ }^{144}$ In most tort contexts, injuring others is not in itself socially beneficial, although the behavior producing injury also may produce social welfare benefits. Intentional infliction of loss in the absence of consent therefore is not generally encouraged. Competition, however, is based on profit from a competitor's loss. Competitive injury in this sense benefits consumers as firms respond to loss by improving the quality or price of their products or services, or by devoting their resources to other pursuits.

${ }^{145}$ Early English cases attempted with mixed results to identify anticompetitive actions by reliance on the defendant's motivation. In Mogul Steamship Co. v. McGregor, Gow \& Co., 23 Q.B.D. 598 (Ct. App. 1889), aff'd, 1892 A.C. 25, steamship companies engaged in the China trade made a concerted effort to drive the plaintiff, a competitive shipper, out of business by offering rebates and low prices and threatening to boycott persons who dealt with him. The court was willing to prohibit acts motivated by pure malice, but found that the defendant's acts constituted competition. Id. at 622 . Pure malice was lacking because "[t]he damage to be inflicted on the plaintiffs was to be strictly limited by the gain which the defendants desired to win for themselves." Id. at 625 .

It was not clear whether the Mogul dictum that ill will might alter the outcome applied only to concerted actions - the tort of conspiracy - or might also apply to individual actions as well. In Allen v. Flood, 1898 A.C. 1, 4-7 (H.L.), the House of Lords held that malice could not transform a lawful act into an unlawful one. This remains the rule in England. Subsequent cases involving the tort of conspiracy, however, have isolated intent to injure the plaintiff as the controlling variable for liability. See, e.g., Crofter Hand Woven Harris Tweed Co. v. Veitch, 1942 A.C. 435, 442-43, 445 (H.L.) (Viscount Simon, L.C.); id. at 452 (Viscount Maugham); id. at 462-63, 467 (Lord Wright).

${ }^{146}$ See text and note at note 156 infra.

167 The Restatement (Second) treatment of malice is singularly unhelpful. The "actor's motive" is one of seven factors listed for determining the impropriety of his interference. Restatement (Second) of TorTs § 767 (1979); see text and notes at notes $39-46$ supra. The only motive discussed in the comment to the section is intent to interfere with the contract. $I d$. $\$ 767$ (b) comment $\mathrm{d}$. In a comment to section 768 dealing with the question of when competition justifies contract interference, the Institute notes that acts based solely on spite or ill will are improper and do not enjoy the justification of competition. Id. \&768 comment g. But see Ethyl Corp. v. Balter, 386 So. 2d 1220, 1226 (Fla. Dist. Ct. App. 1980), in which the court recognized that malice should not negate otherwise privileged behavior because if the behavior is privileged, it cannot be based solely on malice. See also Bourlier Bros. v. 
Moreover, where the defendant's acts are independently tortious, proof of malice is unnecessary except in determining the availability of punitive damages, ${ }^{148}$ or where malice is an element of the independent tort, as in malicious prosecution. The real issue in such cases is whether the plaintiff's loss should fall within the ambit of the defendant's liability at all. ${ }^{149}$ The proper role for motive is more difficult to assess where the defendant's acts are otherwise lawful, but as long as the subject matter of the contract moves to a more highly valued use, the motivation behind the interference seems irrelevant from a social perspective, unless the gains from discouraging acts based on ill will exceed the losses from less efficient resource use. On the other hand, inquiry into the inducer's motive would not necessarily interfere with efficiency in cases where no social gain results from the contract interference, if such cases can be isolated successfully.

An early but well-known case, Tuttle v. Buck, ${ }^{150}$ illustrates this last distinction. The plaintiff was a self-employed barber. The defendant, the town banker, hired a barber on salary to compete with the plaintiff and sought to induce the plaintiff's customers to patronize his shop rather than the plaintiff's. ${ }^{151}$ The plaintiff's petition alleged that the defendant's acts were "in pursuance of [a] wicked, malicious, and unlawful purpose . . ., and for the sole and only purpose of injuring the trade of the plaintiff."152 A majority of the court ruled that the petition stated a cause of action. Justice Elliott, who wrote the opinion notwithstanding his disagreement with the result, viewed the allegation as based on acts by the defendant that were consistent with normal competitive behavior, although perhaps performed maliciously. ${ }^{153} \mathrm{~A}$ majority of the court was apparently content with the proposition that unlawful motive produces liability for acts otherwise lawful. ${ }^{154}$ Justice Elliott, on the other hand, would have required the plaintiff to show that the defendant had conducted his business at a loss or intended to re-

Macauley, $91 \mathrm{Ky} .135,138-39,15$ S.W. 60, 60-61 (1891), in which Kentucky rejected liability in a situation similar to that of Lumley $v$. Gye on the ground that unlawful motives do not render a lawful act unlawful.

14 D. DobBs, supra note 110, \& 3.9, at 204-05; C. MCCormick, HaNdBooK on TḦE LAW of Damages $\S 77$, at 275 (1935).

149 See text and notes at notes 73-75 supra.

${ }^{160} 107$ Minn. 145, 119 N.W. 946 (1909).

151 Id. at 146,119 N.W. at 946.

$152 I d$.

${ }^{163}$ Id. at 151, 119 N.W. at 948.

154 Id. at 151-52, 119 N.W. at 948. 
tire from barbering once the plaintiff was out of business. ${ }^{185}$

This latter formulation of the rule seems superior, because it attempts to isolate noncompetitive facts as a proof of improper motivation. Consumers of barbering services will suffer in the long run from the defendant's activity only if the defendant ceases to act competitively after driving the plaintiff from the market. If he obtains a monopoly, or if his action increases the costs of entry into the barbering market (the cost reflected in the risk of incurring the defendant's animosity), consumers are not benefited in the long run. To be sure, proof of an intent by the defendant to retire from the business once his purpose is accomplished involves a determination of the defendant's state of mind. Objective facts tending to prove this intent, however, also tend to prove lack of competitive benefit. Sales below cost, depending on how cost is defined, are unlikely to represent competitive behavior, as are announced intentions to go out of business.

There is nothing in the efficiency theory to preclude liability for interference where the inducer's objective is something other than to exploit a more advantageous opportunity. These situations are not defined accurately by traditional, simplistic definitions of malice, however; nor are they defined by personal spite or ill will. The key factor is whether the defendant's motivation is compatible with competition. Where it is not, antitrust doctrine in many instances will supply a basis for liability. In others, carefully tailored proscriptions amenable to objective proof should be formulated, rather than a residual category of tortious interference based on subjective motivation. It might be argued that social costs are incurred when parties invest resources in behavior motivated by spite. The scale is weighted heavily against liability for malice alone, however, by the process costs of attempting to isolate malice, the costs of inevitable errors in application, and the costs of precautions by properly motivated actors to avoid liability. ${ }^{188}$

\section{An Unlawful Means Test}

The foregoing analysis suggests that the interference tort should be limited to cases in which the defendant's acts are independently unlawful and that if improper motivation is to give rise

${ }^{155}$ Id. at 151,119 N.W. at 948.

158 Even those who have advocated a broader right to be free from relational interference have recognized that malice, however defined, provides an inadequate explanation for liability. See Freund, supra note 136, at 462. 
to liability, it should be based only on objective indicia of activity producing social loss. In most cases, tort law will provide the standard for judging the unlawfulness of the means. At the same time, those courts that have emphasized unlawful means have recognized that sources other than traditional tort law also might define the lawfulness of the defendant's behavior. ${ }^{167}$ Incorporation of such sources seems right. If the objective of allowing third parties to interfere with contracts is to increase the value of social resources, the definition of unlawful means should be broad enough to cover actions that work at cross purposes with the objective of allocational efficiency, even if those actions are not conventional torts. In a business competition setting, antitrust laws as well as the common law understanding of restraint of trade may serve as a yardstick for liability. ${ }^{158}$ Other regulatory statutes also may serve the same function. Incorporating the fluid doctrines of antitrust into an unlawful means test for tortious interference admittedly will create ambiguity in application, but at least the focus will be, as it should, on the economic effects of the defendant's act. ${ }^{180}$

${ }^{187}$ Inventive Music Ltd. v. Cohen, 617 F.2d 29, 34 (3d Cir. 1980) (applying New Jersey law); Top Serv. Body Shop, Inc. v. Allstate Ins. Co., 283 Or. 201, 209-10, 582 P.2d 1365, 1371 (1978).

${ }^{158}$ See Morton Bldgs. of Nebraska, Inc. v. Morton Bldgs., Inc., 531 F.2d 910, 916-18 (8th Cir. 1976) (applying Nebraska law); Ron Tonkin Gran Turismo, Inc. v. Wakehouse Motors, Inc., 46 Or. App. 199, 611 P.2d 658, 663-64 (1980). Some common approach to prohibited economic activity by antitrust and contract interference doctrine seems appropriate. Antitrust law, however fluid, seeks to facilitate efficient resource allocations, see $\mathrm{R}$. PosNER, Antitrust Law: An Economic Perspective 4, 8-22 (1976), and it is difficult to discern a tort objective that can claim superior attention in this context.

The distinction between protection of competition by antitrust law and protection of competitors by tort law has been used to determine which of the garden-variety common law torts also should subject the perpetrator to antitrust liability. See George R. Whitten, Jr., Inc. v. Paddock Pool Builders, Inc., 508 F.2d 547, 560-62 (1st Cir. 1974), cert. denied, 421 U.S. 1004 (1975). This distinction, however, appropriate in the Whitten context, does not support a tort of interference broader in its reach than antitrust prohibitions when applied to behavior that is not otherwise unlawful. The competitor's only interest protected by the tort is his contractual interest, which is already protected by contract law. Because the objectives of contract and antitrust enforcement are largely compatible, no interest beyond the preservation of competition exists.

On the other hand, a significant number of independent torts arising from the competitive context, such as commercial disparagement, passing off, and trade secret appropriation, may result in contractual losses. Cf. Adler, Barish, Daniels, Levin \& Creskoff v. Epstein, 482 $\mathrm{Pa}$. 416, 393 A.2d 1175 (1978) (former associates of law firm inducing clients of firm to discontinue with firm), appeal dismissed, 442 U.S. 907 (1979). These would all be unlawful means for which the rules proposed here would attach liability.

159 If courts are unwilling to adopt an unlawful means test for tort liability, they at least should limit damages for interference to the contract measure. They also should permit parties to shift liability by contract. 
On the other hand, recognizing an expansive definition of unlawful means does not require recovery of expectancy losses in all cases where some unlawful act occurs. In all of these cases, the issue of whether the contractually based loss should be regarded as within the scope of liability for the unlawful act remains. ${ }^{180}$ For example, where a violation of a regulatory measure is asserted, the proper inquiry will be whether the regulation supports a private right of action. ${ }^{161}$

In the remainder of this part, I apply the foregoing analysis to some representative contract interference cases. These cases fall into three categories distinguished by the focus of the defendant's conduct-conduct directed at the plaintiff, at a person in a relationship with the plaintiff, and at the subject matter on which a contract or prospective relationship depends. The applications highlight a number of difficult questions in fashioning proscriptive legal rules and may explain why courts have preferred to use a broadly applicable tort that can be used to explain, at least superficially, all manner of outcomes. The applications also illuminate how closely the analysis developed in this article reflects the outcomes in decided cases.

\section{A. Acts Directed at the Plaintiff}

The Restatement (Second) of Torts imposes liability for intentionally and improperly preventing another person from performing his contract or for causing his performance to be more expensive, ${ }^{162}$ and for preventing another from "acquiring or continuing [a] prospective relation."16s The defendant in these cases may be a stranger to the severed relationship, ${ }^{164}$ or he may be a discontented promisee seeking to avoid his own contractual obligations by preventing the plaintiff from performing. ${ }^{185}$ In none of

180 The usefulness of the interference tort to define and to limit liability has even been applied in breach of contract cases where the breach serves as the unlawful act. See text and notes at notes 174-175 infra.

161 The test for whether a regulatory statute supports a private cause of action is multifaceted and somewhat uncertain. One issue is whether additional liability upsets the statutorily prescribed scheme of deterrence. See generally Cort v. Ash, 422 U.S. 66, 78 (1975).

162 Restatrment (Second) of Torts § 766A (1979).

16ฐ Id. § 766B.

${ }_{104}$ See, e.g., Lichter v. Fulcher, 22 Tenn. App. 670, 125 S.W.2d 501 (1938) (public contract requiring use of union labor disrupted when the defendant, a local union, refused to supply labor to the plaintiff).

${ }^{165}$ Cf. Fradus Contracting Co. v. Taylor, 201 A.D. 298, 194 N.Y.S. 286 (1922) (plaintiff's contract with New York City to unload scows on Riker's Island disrupted when the commis- 
these situations does it appear necessary to create a separate tort as a basis for liability. Where the promisee attempts to interfere with his promisor's performance, the promisee is likely to be liable for breach of a specific contractual provision or the general obligation of contracting parties to act in good faith. ${ }^{168} \mathrm{In}$ cases of thirdparty interference with performance, the plaintiff, who is complaining of the interference, is unlikely to have been a willing participant in the interference: many such cases will involve fraud, force, or other independently unlawful acts. ${ }^{167}$

In any event, an unlawful means test accounts for the cases cited by the drafters of the Restatement (Second) in support of liability. ${ }^{168}$ A recurring factual pattern in several of the cited cases involves the defendant preventing the plaintiff from entering premises where the contract was to be performed. In a number of the cases, where the defendant was the promisee, breach of the contractual duty of good faith provides a basis for liability. ${ }^{109}$ In

sioner of street cleaning refused permission to use the city's docks for the unloading).

${ }^{108}$ There is an implied condition in contracts, often described as part of the duty to act in good faith, that one party to a contract not hinder or make more expensive the other's performance. See 5 S. Williston, A Treatise on the LaW of Contracts § 677A (3d ed. 1961). The injured party may excuse his own performance and sue for breach. Barron v. Cain, 216 N.C. $282,284,4$ S.E.2d 618, 620 (1939). Damages may include lost profits from future sales. See Winegar v. Gray, 204 Cal. App. 2d 303, 313-14, 22 Cal. Rptr. 301, 307-08 (1962). But see Hough v. Jay-Dee Realty \& Inv., Inc., 401 S.W.2d 545, 550 (Mo. Ct. App. 1966) (per curiam) (lost profits conceded to be unascertainable where the hindrance prevented a new business from beginning). For an analysis of the good faith obligation, see Burton, Breach of Contract and The Common Law Duty to Perform in Good Faith, 94 HARV. L. REv. 369 (1980).

${ }_{187}$ The language of the Restatement (Second) supports this point. Section 766A speaks of the defendant's "preventing" performance, whereas section 766 speaks of the defendant's "inducing" nonperformance.

${ }^{168}$ Restatement (Second) of ToRTs $\$ 766(2)$ note to Institute, at 30 (Tent. Draft No. 14, 1969).

${ }^{169}$ See Fradus Contracting Co. v. Taylor, 201 A.D. 298, 194 N.Y.S. 286 (1922) (plaintiff's performance of contract with city prevented by city official). See also White v. Massee, 202 Iowa 1304, 211 N.W. 839 (1927). In White, a father promised his daughter that if she took care of him for life he would give her the 160-acre homestead. The daughter moved onto the homestead, paid the taxes and insurance, and cared for her father. Id. at 1305, 211 N.W. at 840 . Subsequently the father and daughter had a disagreement and the father deeded the homestead to his son. Id. at 1307, 211 N.W. at 840. The son asked the daughter to move out; she then sought an injunction to restrain the son from interfering with the performance of her contract with their father and "to protect her in performance, to the end that she may ultimately be in a position to claim and secure the benefits of the contract." Id. at 1308, $211 \mathrm{~N}$.W. at 841. The court found the contract enforceable if the plaintiff stood willing to perform and recognized the plaintiff's right to place a trust on the property upon the father's death. Id. at $1308,211 \mathrm{~N} . W$. at 841 . The injunction was an equitable response in what amounted to a quiet title action over the ownership of the homestead. Arguably, the contract conferred equitable title on the plaintiff, and the action was one to prevent a 
two other cited cases, involving a railroad's refusal to deliver consigned goods to a freight hauler ${ }^{170}$ and a public stockyard's refusal to allow a cattle buyer to enter the yard, ${ }^{171}$ the defendants' behavior probably violated restraints on discrimination by common carriers and public utilities. ${ }^{172}$ Other cited cases involved labor union activity with clear anticompetitive purposes and effects. ${ }^{173} \mathrm{Al}-$ though the courts in these cases properly focused on the disrupted economic expectancy as the element of damage, in none of the cases was the fact of interference necessary to determine the ap-

trespass.

170 Southern Ry. v. Chambers, 126 Ga. 404, 55 S.E. 37 (1906).

171 Bacon v. St. Paul Union Stockyards Co., 161 Minn. 522, 201 N.W. 326 (1924) (per curiam).

172 At common law and under state and federal legislation, a common carrier is bound to furnish transportation facilities to all persons under like conditions without discrimination. See 49 U.S.C. $\$ 10,741$ (Supp. III 1979); Iowa CodE $\$ 327 D .8$ (1977); Northern Gravel Co. v. Muscatine N. \& S. Ry., 185 Iowa 1259, 171 N.W. 787, 789-90 (1919); Barlotti \& Son v. Public Util. Comm'n, 103 Ohio St. 647, 658-59, 134 N.E. 468, 471 (1921). By statute and at common law, a public warehouse is a public utility and must treat all comers impartially. See 93 C.J.S. Warehousemen \& Safe Depositaries \& 8 (1956); see also Gray v. Central Warehouse Co., 181 N.C. 166, 175, 106 S.E. 657, 661 (1921); Port of Seattle v. Luketa, 12 Wash. 2d 439, 442, 121 P.2d 951, 953 (1942). In addition, federal law provides that "[i]t shall be the duty of every stockyard owner and market agency to . . . enforce . . . nondiscriminatory regulations and practices in respect to the furnishing of stockyard services." 7 U.S.C. \$208(a) (1976).

In tracing the concept of economic duress as it applies to invalidate contracts, Professor John Dawson discussed the early use of the economic coercion doctrine in public utilities cases to invalidate unreasonable charges. Dawson, Economic Duress-An Essay in Perspective, 45 MIcH. L. REv. 253, 260-61 (1947). He noted that the doctrine was extended to agencies not normally considered public utilities, such as universities. Id. at $261 \mathrm{n} .24$ (citing Niedermeyer v. Curators of the Univ. of Mo., 61 Mo. App. 654 (1895)). Although economic duress normally has been viewed as a doctrine to invalidate agreements, its use as a test for tort liability seems proper: a plaintiff who "buys his way out" of a threatened refusal to deal should be no better off than the plaintiff who complies with the threat to his injury. An unlawful means test incorporating the contract definition of economic duress ensures that an interference will be actionable in tort only when it also would be actionable in contract. See also Dalzell, Duress by Economic Pressure (pt. 1), 20 N.C.L. Rev. 237, 243-46 (1942).

More recent cases have indicated that liability will be extended to other quasi-monopoly situations where refusal to deal directly restrains trade. See Program Eng'r, Inc. v. Triangle Publications, Inc., 634 F.2d 1188, 1195 (9th Cir. 1980) (racetrack); Greenberg v. Hollywood Turf Club, 7 Cal. App. 3d 968, 976-77, 86 Cal. Rptr. 885, 890-91 (1970) (racetrack); Grillo v. Board of Realtors, 91 N.J. Super. 202, 227-28, 219 A.2d 635, 647-48 (1966) (multiple real estate listing service).

17s Yankee Network, Inc. v. Gibbs, 295 Mass. 56, 3 N.E.2d 228 (1938) (musicians' union local prevented members from working for plaintiff, where plaintiff sought to engage nonlocal conductor); Lichter v. Fulcher, 22 Tenn. App. 670, 125 S.W.2d 501 (1938) (refusal to supply plaintiff, a nonlocal contractor, with labor to protect local contractors from competition); Pacific Typesetting Co. v. International Typographical Union, 125 Wash. 273, 216 P. 358 (1923) (union refusal to supply labor to $A$ so that $A$ could not perform contract with $B$, where union had dispute with $B$ ). 
propriateness of the defendant's behavior; in each case that behavior was at least arguably independently unlawful.

The last case cited in support of the Restatement (Second) rule, Sumwalt Ice \& Coal Co. v. Knickerbocker Ice Co., ${ }^{174}$ nicely illustrates how courts used the interference tort to limit recovery for economic loss from breach of contract. The defendant sold ice to a dairy in violation of an agreement with the plaintiff not to sell ice directly to the plaintiff's customers. The issue was whether the plaintiff's loss of profit from its contract with the dairy was recoverable from the defendant. Use of the interference tort can be explained as a device to allow recovery by the plaintiff while limiting the defendant's liability. Without such a limit, anyone suffering economic loss because of the breach arguably could recover, including the plaintiff's creditors or employees.

Although the cases cited in support of the Restatement (Second) rule are consistent with an unlawful means analysis, other cases are more difficult to reconcile with such a test. These cases seem to use the interference tort as a catch-all for recovery of economic loss, creating unnecessary doctrinal confusion. In one case, a lessor's willful refusal to make structural repairs to retained portions of leased premises was held to constitute intentional interference with the lessee's expected business profits. ${ }^{175}$ In imposing tort liability, the court emphasized that the landlord's refusal was motivated by a desire to oust the lessee and to put the premises to more profitable use; however, the court also recognized that the defendant "should not be held liable in tort for a willful breach of an agreement which it is no longer economically feasible for the party to respect," because "in such an instance [the defendant is] at 'legal liberty' to breach the agreement upon payment of ordinary contract damages demonstrated to have resulted from the breach."178 Use of the interference tort complicated the case unnecessarily. A landlord's duty to repair retained portions of leased premises normally is regarded as arising out of independent tort obligations and not out of the lease itself. ${ }^{177}$ Assuming this tort duty was breached, the only issue is whether the lessee's economic expectancy losses were recoverable. Application of the contract interference tort allowed the lessee to recover without opening the

\footnotetext{
174114 Md. 403, 80 A. 48 (1911).

175 Cherberg v. Peoples Nat'l Bank, 88 Wash. 2d 595, 605, 564 P.2d 1137, 1144 (1977). 176 Id.

177 See REstatement (Second) of Torts § 360 (1979).
} 
floodgates to recovery of economic loss by others, but at the same time, the court created a misleading precedent, holding, as it was forced to do by the facts, that a person can be liable for intentionally interfering with his own contract. ${ }^{178}$

Courts also have relied on tort doctrine in a few cases where the defendant, a lessor or franchisor, reserved the right to approve any sublease. When approval was denied, the original lessee sued the defendant for interference with the potential sublease. In two cases, the defendant was held to be privileged for exercising his right to disapprove. ${ }^{179}$ In another, where the lessor subsequently leased the building to the disapproved sublessee, the court indicated that tort liability could be imposed for contract interference and reversed summary judgment for the defendant. ${ }^{180}$ These cases all involve the good faith exercise of contractual rights-an issue that properly is governed by contract law, not tort law. By treating the question as one of privilege, even those cases that denied liability confused the issue. Under an unlawful means test, the focus is where it should be-on the contractual propriety of the defendant's exercise of his contractual power of refusal.

\section{B. Acts Directed at the Subject Matter of the Contract}

The Restatement (Second) also imposes liability where the plaintiff's performance is made more expensive by an intentional and improper act directed at the subject matter of the contract. ${ }^{181}$ The issue in such cases is not whether the contract will be performed, but only at what cost; the promisee therefore has no interest in the controversy. Two famous old cases, McNary $v$. Chamberlain $^{182}$ and Cue v. Breeland, ${ }^{183}$ are thought to support the imposition of liability in such circumstances. ${ }^{184}$ In both cases, the plaintiffs were obligated by contract to maintain in repair property

178 See also Yaindl v. Ingersoll-Rand Co. Standard Pump-Aldrich Div., 422 A.2d 611, 618 (Pa. Super. Ct. 1980) (recognizing cause of action for wrongful discharge of an at-will employee as a "particularized instance of a more inclusive tort of intentional interference with the performance of a contract") (footnote omitted).

170 Comini v. Union Oil Co., 277 Or. 753, 562 P.2d 175 (1977); Serafino v. Palm Terrace Apartments, Inc., 343 So. 2d 851 (Fla. Dist. Ct. App. 1976), overruled, Ethyl Corp. v. Balter, 386 So. 2d 1220, 1226 (Fla. Dist. Ct. App. 1980).

${ }^{180}$ Homa-Goff Interiors, Inc. v. Cowden, 350 So. 2d 1035, 1038 (Ala. 1977).

181 Restatement (Second) of ToRts § 766A (1979).

16234 Conn. 384 (1867).

1ss 78 Miss. 864,29 So. 850 (1901).

se4 Restatement (Second) of ToRTs $\S 766(2)$ note to Institute, at 30 (Tent. Draft No. 14, 1969). 
owned by another-a highway in McNary and a bridge in Cue. The defendants damaged the property, forcing the plaintiffs to make repairs. ${ }^{185}$

Both courts held the defendants liable to the plaintiffs for the cost of the repairs, but it is unlikely that either court thought it was creating a tort for contract interference. The damage in each case resulted from a trespass, and both actions were brought in trespass. ${ }^{188}$ Ordinarily, the defendants would have been liable in tort to the owners of the property, but because of the repair contract, the plaintiffs rather than the owners suffered the loss. In effect, the repair contract subrogated the plaintiffs to the owners, much as a lease gives the tenant standing to sue for trespass to leased premises, ${ }^{187}$ or as a bailment contract gives the bailee the right of action for conversion of bailed property by a third party, ${ }^{188}$ or as an insurance contract subrogates an insurer to the insured. ${ }^{189}$ 850.

${ }^{185}$ McNary v. Chamberlain, 34 Conn. at 384; Cue v. Breeland, 78 Miss. at 864, 29 So. at

286 McNary v. Chamberlain, 34 Conn. at 384-85; Cue v. Breeland, 78 Miss. at 864, 29 So. at 850 .

${ }_{187}$ "The lessee has the benefit of all the remedies available to the owner of any other possessory estate in land and may proceed in his own behalf directly against the wrongdoer." I American LAW of Property § 3.53, at 286 (A.J. Casner ed. 1952) (footnote omitted). The tenant also can recover possession when another has taken it before the tenant's entry. Restatement (Second) of Property $\$ 6.2$ (Tent. Draft No. 1, 1973). For the owner and not the tenant to have standing to sue, the owner must show harm to his reversionary interest. W. ProssER, supra note $2, \S 13$, at 69 . Generally the tenant can sue only for harm to his leasehold unless he has an obligation to repair. See California Dry-Dock Co. v. Armstrong, 17 F. 216, 218 (C.C.D. Cal. 1883); Logan Cent. Coal Co. v. County Court, 106 W. Va. 578, 146 S.E. 371 (1929).

${ }^{188}$ See W. Prosser, supra note $2, \S 15$, at 95.

189 If the plaintiffs in McNary and Cue had agreed to insure the property against damage rather than to keep the property in repair themselves, the outcome would have been essentially the same. A property insurer at common law was subrogated to the owner's claim against third persons. W. VANCE, INSURANCE $\$ 134$, at 786-90 (3d ed. 1951). As insurers, the plaintiffs could have paid for damage to the property, then recovered from the defendants. This recovery under subrogation would not depend on whether the defendants had intended to interfere with the insurance contract.

On the other hand, life insurers in a number of cases have been denied recovery against defendants who have murdered the insured. See note 65 supra. Such cases are directly analogous to McNary and Cue except that a life insurer cannot be subrogated against third parties. W. VANCE, supra, § 134, at 787, 796-97. Thus, for the life insurer to recover, some independent tort must be created. It was suggested in one case that if the defendant murdered the insured with specific intent to injure the insurer, liability might be imposed. Connecticut Mut. Life Ins. Co. v. New York \& N.H.R.R., 25 Conn. 265, 276 (1856). These life insurance cases perplexed Dean Prosser in his attempt to fashion the requisite intent for the interference tort. See note 19 supra. They are cited as examples of cases where the defendant can be substantially certain that the interference will occur, yet not be liable unless his intent was directed specifically at the insurer. See id. No general proposition should be 
In all of these cases, the defendant's liability cannot exceed the value of the physical damage. Where more than one person has an interest in the damaged property, each recovers only to the extent of that interest. ${ }^{190}$ These analogies clarify that McNary and Cue announced no new principle of substantive tort liability. The interference tort may be a useful way in subject matter cases to reach a result that limits liability for economic loss within reasonable bounds, but at the same time, it is particularly important in these cases to confine the tort to unlawful acts. For example, assume in a case like McNary or Cue that the defendant is not at fault in damaging the property and thus is not liable to the owner. The impact on the plaintiff repairer is the same. If tort liability is extended to any interference otherwise lawful, liability depends on the fortuity of whether the owner of the property is insured or has contracted for repairs. ${ }^{191}$

drawn from these cases, however. They merely reflect that the rule against subrogation of a life insurer would be undercut if tort liability were recognized. Life insurance is regarded not only as an indemnity contract, but also as an investment. See, e.g., Penn Mut. Life Ins. Co. v. Lederer, 252 U.S. 523, 529 (1920). Presumably, the rule against subrogration rests in part on preventing the insurer from competing with the insured or his heirs for proceeds of a fund created for investment. Furthermore, because the amount of insurance allowed to be carried on one life is not limited by any objective fair market value standard, recognition of an independent claim by the insurance company could multiply the defendant's liability by a factor solely determined by the deceased's willingness to insure.

Life insurance policies are designed to shift the risk of acts directed at the insured from his heirs to the insurance company. Premiums for life insurance are based on actuarial calculations that may or may not include risk of death from human as well as natural causes. The insurance principle teaches that risks become predictable when spread over large numbers of persons. In other words, the insurance company expects a certain number of deaths (payouts) each year for any given risk pool. If tortious deaths are used to determine the premium, the tortious act of a third person directed at a single insured in a pool does not in any economic sense make the insurance company's performance more expensive than it reasonably expected when it established the premiums for the pool. As long as the company knows the rule regarding its rights of subrogation, it can suffer no economic loss. The risk that cannot, or at least is unlikely to, be determined actuarially in setting premiums is the risk that someone will direct acts at an insured solely to cause the insurance company loss. Only in such an unlikely case can recovery by the insurance company be justified.

Some American Law Institute members even questioned whether to include the insurance company problem in the sections on interference. See 46 ALI Prockedings, supra note 19, at 212-216. Professor Allan McCoid thought they should not: "I'm sorry. I'm not a contract lawyer, but I have never assumed that it was interference with a contract to require one to perform it." Id. at 214. He agreed, however, that bringing about an insured event did make performance more expensive. Id. at 215.

${ }^{290} \mathrm{~W}$. Prosser, supra note $2, \S 15$, at 96-97.

102 Application of a malice standard to make lawful acts unlawful runs the risk of costly errors in cases involving interference with the subject matter of the contract. Suppose that $A$ agrees to supply widgets to $B$ at $\$ 10$ each and contracts with $T P$ to purchase the widgets wholesale for $\$ 5$ each. Suppose, too, that the wholesale market price for widgets subse- 
C. Acts Directed at a Person in a Relationship with the Plaintiff

The most numerous of the tortious interference cases are those in which the disruption is caused by an act directed not at the plaintiff, but at a third person: the defendant causes the promisor to breach his contract with the plaintiff or causes a third person not to confer a benefit on the plaintiff. This factual pattern is more complex than others for several reasons. If some wrong is committed against the promisor that causes him to breach, the promisee's loss is one step removed from the focus of the defendant's act. Liability is extended beyond the directly injured party to one in an economic relationship with him. If no independently unlawful act is employed, the promisor in most cases is a willing and benefited participant in the behavior that causes the plaintiff's loss. The interests of the two contracting parties diverge. It is in this situation that social gain is most likely to result from the interference. To test whether an unlawful means test properly isolates behavior causing social loss, I review four recurring categories of cases to which the tort has been applied.

1. Competitive Cases. In most jurisdictions, the fact of competition alone does not justify interference, and at least a prima facie case of liability attaches if the competitor intentionally interferes with a known contract. ${ }^{192}$ Defendants have been held liable for offering lower prices with knowledge of an existing contract ${ }^{193}$ and for seeking to replace the plaintiff as an exclusive agent or

quently increases to $\$ 8$ and $T P$ raises his price to that amount. If $A$ pays the increased price, his performance of the supply contract with $B$ is made more expensive. As a matter of contract law, the issue between $A$ and $T P$ is whether $T P$ breached his contract. If the contract was terminable at will and the price of the widgets was to be determined on the date of sale, $T P$ is not liable to $A$. But under the Restatement (Second), TP's action would be subject to tort liability if "improper," and in many jurisdictions TP would bear the burden of persuading the factfinder that his actions were justified. The strongest case for tort liability must be where $T P$ acts with actual malice toward $A$ and without any socially redeeming motivation. It is difficult to see, however, how the adoption of a tort theory adds much to the plaintiff's arsenal. If a breach of contract occurred, $A$ will recover the difference between the market price and the contract price. In the unlikely case that $T P$ raised his price above market price to spite $A, A$ will do better buying in the market. If TP's actions were not a breach of the contract, adoption of tort liability would result in protecting $A$ against a risk-rise in market price-against which he could have protected himself by negotiating for a long-term supply contract. TP's motivation seems irrelevant. Even if we might wish to deter legal acts done maliciously, TP's actions are valuable enough, if not maliciously motivated, to protect from the potential errors of an inquiry into subjective motivation. Pricing decisions are always difficult to regulate on the basis of motivation.

102 W. Prosser, supra note $2, \S 129$, at 945.

${ }^{103}$ Westinghouse Elec. \& Mfg. Co. v. Diamond State Fibre Co., 268 F. 121, 128 (D. Del. 1920); Cumberland Glass Mfg. Co. v. DeWitt, 120 Md. 381, 392-94, 87 A. 927, $931-32$ (1913). 
dealer by offering better terms. ${ }^{194}$ In one case, the defendant offered to sell goods at a lower price and actually made sales before he was informed of his buyer's contractual obligation to buy exclusively from the plaintiff. The court held the defendant liable for "continuing inducements" after the knowledge was obtained. ${ }^{195}$ Other courts have held that a competitor may be obliged in some circumstances to investigate whether a contract exists. ${ }^{186}$

A number of cases seem to involve plaintiffs using the contract interference tort to protect their own anticompetitive activities. In Imperial Ice Co. v. Rossier, ${ }^{197}$ the disrupted contract was an agreement by the seller of a business not to compete with the buyer. Because the agreement was unlimited in time, its enforceability was at least suspect. ${ }^{198}$ Nonetheless, the buyer persuaded the court to enjoin a third party from supplying the seller with goods that had allowed the seller to compete. In Westinghouse Electric \& Manufacturing Co. v. Diamond State Fibre Co., ${ }^{199}$ the defendant was preliminarily enjoined from selling unpatented supplies to a patent owner's licensees, on the theory that the sales constituted tortious interference with a licensing provision requiring the licensees to purchase such supplies from the patent owner. In another case, the Sperry and Hutchinson Company prevented stamp exchanges from trafficking in $\mathbf{S} \& \mathrm{H}$ stamps by claiming that the exchanges had interfered with an $\mathrm{S} \& \mathrm{H}$ contract provision making the stamps nontransferable 200 - a practice subsequently attacked as unfair by the Federal Trade Commission. ${ }^{201}$ These cases illustrate the social loss that results from liability for contract interference by lawful means. Moreover, indiscriminate application of the interference tort increases the risk that parties will be able to

194 Beekman v. Marsters, 195 Mass. 205, 209-13, 80 N.E. 817, 818-20 (1907). See also Sorenson v. Chevrolet Motor Co., 171 Minn. 260, 214 N.W. 754 (1927) (reversing grant of demurrer). 1920).

${ }^{198}$ Westinghouse Elec. \& Mfg. Co. v. Diamond State Fibre Co., 268 F. 121, 128 (D. Del.

${ }^{196}$ For example, recording may give rise to constructive knowledge and a duty to investigate. See Gruen Indus., Inc. v. Biller, 608 F.2d 274, 282-83 (7th Cir. 1979) (discussing Wisconsin cases involving agricultural cooperative contracts required by state law to be recorded).

19718 Cal. 2d 33, 112 P.2d 631 (1941) (en banc). 1977).

198 Restatement (Second) of Contracts $\S 330(1)$ comment d (Tent. Draft No. 12,

199 268 F. 121, 129-30 (D. Del. 1920).

200 Sperry \& Hutchinson Co. v. Louis Weber \& Co., 161 F. 219 (C.C.N.D. Ill. 1908).

201 See FTC v. Sperry \& Hutchinson Co., 405 U.S. 233 (1972). The Supreme Court set aside the FTC's determination. 
evade contract policies such as that against enforcement of contracts in restraint of trade. ${ }^{202}$

Expansive tort liability also may conflict with antitrust law. The potential overlap is illustrated by Engine Specialties, Inc. $v$. Bombardier, Inc. ${ }^{203}$ a case involving cancellation of exclusive dealerships. Engine Specialties ("ESI") was the exclusive North American dealer for a minicycle manufactured by Agrati. The dealership agreement provided for six months' notice to terminate and prohibited Agrati from marketing the minicycle in North America for two years following termination. Bombardier, a large snowmobile manufacturer, wanted to enter the minicycle market, but instead of making its own minicycle, it induced Agrati to terminate its agreement with ESI and to breach the two-year marketing prohibition. ${ }^{204}$ ESI sued Bombardier and won treble damages under the antitrust laws and tort damages for contract interference. ${ }^{205}$

ESI's antitrust claim depended upon proof that the agreement between Bombardier and Agrati was an illegal division of markets between competitors ${ }^{206}$ and that the injury resulted from the antitrust violation. ${ }^{207}$ On the latter issue, Bombardier argued unsuccessfully that a unilateral switching of dealers is not a per se antitrust violation and that because the plaintiff would suffer the same injury from a unilateral switching, no causal connection to the antitrust violation could be shown. ${ }^{208}$

Whatever the result on the merits, the resolution of these issues does not belong to tort law. ${ }^{209}$ Whether the market division was unlawful and whether that illegality supported the plaintiff's claim for damages should be for antitrust law to decide. Whether substitution of dealers is anticompetitive also seems to be part of

${ }^{202}$ On the unenforceability of contracts in restraint of trade, see generally $14 \mathrm{~S}$. WiLLISton, A Treatise on the LaW on Contracts $\$ 1635$, at $82-88$ (3d ed. 1972).

${ }^{203} 605$ F.2d 1 (1st Cir. 1979), cert. denied, 446 U.S. 983 (1980).

201 Id. at 3-6.

${ }^{205}$ Id. at 20.

208 Id. at 8.

207 Id. at 12-15.

${ }^{208}$ Id. Because Bombardier had the necessary "desire, intent, and capability" to enter the market by producing its own motorcycles, $i d$. at 10 , and because the language of the contract between Bombardier and Agrati "embraced territorial restrictions," id. at 10-11, the court concurred that the agreement was between competitors and was therefore per se unlawful. Id. at 11. The court then concluded that the plaintiff's injury was caused by the antitrust violation. $I d$. at 15 .

${ }^{200}$ The court made a passing but vague reference to various "unfair or illegal" acts including deception directed at the plaintiff's contract. Id. at 14. It is unclear whether proof of these acts was independently sufficient to support tort liability. 
antitrust jurisprudence. ${ }^{210}$ No clear reason exists why tort law should supplement or supercede the antitrust resolution of these questions. Limiting tort liability for contract interference to cases of unlawful acts ensures that the tort will not be used to circumvent or contradict antitrust policies. ${ }^{211}$ In Engine Specialties, imposition of tort liability seems supportable, either because the means of interference were unlawful under antitrust law, or because objective facts indicated anticompetitive purpose and effect. 212

The outcomes of other cases, however, are sometimes harder to reconcile with an unlawful means test. In particular, cases in which a party uses superior economic power to effectuate a modification or breach of existing contractual relationships seem to test the limits of an unlawful means approach. Hannigan v. Sears, Roebuck \& $\mathrm{Co}^{213}$ is illustrative. Hannigan had designed an outdoor storage locker. Fabricated Products manufactured the lockers under an agreement to sell them exclusively to Hannigan. Hannigan then sold the lockers to Sears. Fabricated also manufactured outdoor storage buildings, which it sold directly to Sears. ${ }^{214}$ To avoid Hannigan's middleman mark-up, Sears became interested in purchasing lockers directly from Fabricated. To that end, Sears announced a plan whereby it would buy all outdoor buildings and lockers from a single source. ${ }^{215}$ To continue to sell buildings to Sears, Fabricated would have to breach its agreement to sell lockers exclusively to Hannigan. Because Fabricated could not survive without the sales to Sears, and because Hannigan depended on Fabricated to manufacture its lockers, the parties modified the ex-

210 Antitrust law is ambiguous as to when refusals to deal are actionable. Although the articulated doctrine requires some concerted action, the line between concerted and individual refusals to deal is not bright. See United States v. Parke, Davis \& Co., 362 U.S. 29, 36-45 (1960) (discussing the case law on refusals to deal). See also Cernuto, Inc. v. United Cabinet Corp., 595 F.2d 164, 166-70 (3d Cir. 1979). There is precedent for tort liability based on inducing a switch of dealers. Sorenson v. Chevrolet Motor Co., 171 Minn. 260, 214 N.W. 754 (1927). But see Justice Royal A. Stone's dissent, recognizing that "breach may be laudable morally and the inciting advice legally blameless." Id. at 269, 214 N.W. at 757.

${ }^{211}$ Of course, recognizing an antitrust violation as an unlawful means of interference does not require that liability attach to all private losses. See text and notes at notes 160 161 supra.

21: On the other hand, cases may arise in which the means of interference do not violate the antitrust laws and the effect of interference is not anticompetitive. In those cases, tort liability would be without foundation under an unlawful means test.

21s 410 F.2d 285 (7th Cir.), cert. denied, 396 U.S. 902 (1969).

214 Id. at 288.

21 Id. at $288-89$. 
clusive sales agreement to allow Fabricated to sell directly to Sears. ${ }^{218}$ Hannigan in return received a ten percent commission on the sales to Sears-a substantial reduction from its mark-up as middleman under the prior relationship. The court, characterizing Sears's conduct as "intentionally coercive and oppressive," approved an award in favor of Hannigan of both compensatory and punitive damages, holding that the interference tort applied to modifications as well as breaches of contract. ${ }^{217}$

Imposing liability for inducing contract modification seems ill advised, as long as the means of inducement are lawful. If contracting parties agree to a modification, they must believe themselves to be better off than they would be by complying with or breaching the original undertaking. Hannigan, rather than acceding to the new arrangement, could have let Fabricated breach and then relied on his contract remedies. If Fabricated then had gone bankrupt, it would have been because the original contract was built on artificial prices that the parties could not maintain under competitive pressure. Moreover, making induced modifications actionable reduces the reliability of such modifications, because parties can agree to a modification, then sue in tort. Liability also reduces the incentives for third parties to offer opportunities by which all three parties can gain more than by the original transaction.

Under an unlawful means test, the central question is whether the use of economic power to alter an existing contract is independently unlawful. ${ }^{218}$ Ordinarily this question seems more properly a matter of antitrust law than tort law, because the major function of antitrust law is to define the limits of economic power. To the extent the defendant has a monopoly or conspires with others to secure some advantage, antitrust law appears available to intercede. $^{219}$ In Hannigan, however, Sears was under no contractual obligation to buy from Fabricated, and even if Sears knew of the Fabricated-Hannigan contract, antitrust law presumably would authorize Sears to announce and to implement its single source purchase plan. ${ }^{220}$ Beyond the single-source plan, it is difficult to

218 Id. at 290.

217 Id. at 294.

218 The court asserted that a ruling in favor of Sears would "invite today's superior economic forces to freely interfere with contractual relationships without fear of legal reprisal." Id. at 291.

219 See note 172 supra.

${ }^{220}$ See United States v. Colgate \& Co., 250 U.S. 300, 306-08 (1919) (individual refusals 
find anything in the negotiations leading to the modification that was "coercive."221 To all appearances, the means of inducement were lawful. Without additional facts, it may be assumed that the real reason Fabricated and Hannigan were willing to modify their agreement was that existing or potential competitors were willing to produce the lockers at a lower price. The price advantage enjoyed by Fabricated and Hannigan presumably resulted from the cost of entry, including the cost of reverse-engineering the lockers. The application of the interference tort to Sears may have no other effect than to increase those costs of entry by removing Sears from the market. An unlawful means test would avoid this result.

2. Personal Service Relationships. a. Inducing employee breach. When a third party encourages another's employee to breach his employment contract, he may merely be competing with the original employer for the employee's services. As efficient breach theory explains, the employee's change of employment offers an opportunity for social welfare gains, at least where the means of inducement are lawful.

Consistent with efficient breach theory and unlawful means analysis, the use of unlawful means to procure another's employee is widely held to be actionable regardless of the nature of the employment contract.222 Where lawful means are used, however, courts sometimes impose liability, depending on the nature of the employment contract. The results are not always consistent with efficient breach. Competition by otherwise lawful means for employees not contractually bound to their employment is permissible, and most courts have articulated a rule that allows one employer to solicit a competitor's employees if the employment contract is terminable at will and the solicitation is for a lawful purpose. ${ }^{223}$ Where the contract is for a definite term, however, it is likely that most courts would impose liability for procuring breach even if lawful means of inducement are used, as long as the defendant knew of the contract, intended to procure a breach, and could

to deal do not violate antitrust laws).

222 See United States v. Parke, Davis \& Co., 362 U.S. 29, 45-47 (1960) (concerted refusals to deal to enforce resale price maintenance plan violate antitrust law).

228 Annot., 24 A.L.R.3d 821 (1969).

${ }^{123}$ This is the effect of RESTATEMENT (SECOND) OF TORTS $§ 768$ (1979), which announces that competition justifies interference with at-will relationships. The rule is recognized particularly in cases finding an unlawful motive or means. See, e.g., Globe \& Rutgers Fire Ins. Co. v. Fireman's Fund Ins. Co., 97 Miss. 148, 52 So. 454 (1910). 
not assert any justification for the interference. ${ }^{224}$ Although the second employer must actively induce breach to be liable for interference and will not be liable for merely hiring an employee who has breached another employment contract, ${ }^{225}$ the line between permissible and impermissible behavior in the decided cases is fine, ${ }^{226}$ and it seems likely that some socially valuable behavior will be discouraged as parties take precautions against liability. An unlawful means test would avoid this social loss.

In some cases involving employment relationships terminable at will, courts have strained to discover some improper purpose or unlawful method upon which to fasten liability. An illustrative case is Wear-Ever Aluminum, Inc. v. Townecraft Industries, Inc., ${ }^{227}$ in which the defendant was found liable for appropriating the plaintiff's sales organization. Both parties were in the business of selling cooking utensils door-to-door; the method was a three-tiered sales organization consisting of distributors, dealers, and district managers, all with employment contracts that were terminable at will. Distributors conducted door-to-door sales and were supervised by dealers, who in turn were supervised by district managers. Compensation at all levels depended upon commissions on sales produced by the district as a whole, and a team concept was utilized. ${ }^{228}$ By inducing one of Wear-Ever's district managers to change employers, Townecraft was able to secure the entire distribution organization for that district. ${ }^{229}$ Although there was a hint of misrepresentation, ${ }^{230}$ the court based liability on Townecraft's appropriation of the entire sales force with intent to injure WearEver. ${ }^{231}$

224 See W. Prosser, supra note 2 , § 129 , at 930-31. This is the effect of Restatement (SECOND) OF TORTS $\$ 768(2)$ (1979), which denies a competitive privilege for inducing breach of an existing contract. See also Walker v. Cronin, 107 Mass. 555, 563-64 (1871); Lumley v. Gye, 2 El. \& Bl. 216, 222-25, 118 Eng. Rep. 749, $752-55$ (Q.B. 1853) (Crompton, J.).

${ }^{223}$ Purcell v. Joyner, $231 \mathrm{Ga} .85,88,200$ S.E.2d 363, 366 (1973).

${ }^{228}$ See id. (no evidence of inducement "other than simply stating that there is a job available that pays such and such an amount. ... There is no evidence of a solicitation with a purpose to harm . . . the employer . . . nor is there evidence [that the defendant] actively induced, conspired with or aided and abetted [the employee] to break his contract.").

22775 N.J. Super. 135, 148, 182 A.2d 387, 395 (Ch. Div. 1962).

${ }^{228} \mathrm{Id}$. at $138-39,182 \mathrm{~A} .2 \mathrm{~d}$ at 389.

228 Id. at $141,182 \mathrm{~A} .2 \mathrm{~d}$ at $390-91$.

${ }^{230}$ Id. at $144,182 \mathrm{~A} .2 \mathrm{~d}$ at $392-93$.

${ }^{231}$ Id. at $142,145-46,182$ A.2d at 391,393 . A case similar to Wear-Ever is Buxbom v. Smith, 23 Cal. 2d 535, 145 P.2d 305 (1944), in which the defendant hired the plaintiff to distribute the defendant's handbills. The plaintiff recruited crews to make the distribution. The defendant breached the contract and subsequently hired the crews himself. The plain- 
Wear-Ever appears to be an anomaly even under traditional doctrine, which allows competition for at-will employees. It may be possible, however, to distinguish the appropriation of large numbers of employees from cases involving single employees. Employers will be reluctant to invest the cost of training employees or to disclose secret information to them if they cannot capture the returns such training or disclosure can produce. To the extent competitors are allowed to hire away valued employees, they are given a free ride on the original employer's investment. On the other hand, if the law secured for the employer all of the gains from this investment, rigid restrictions on employee mobility would have to be enforced, and employees would be less willing to accept training or information. ${ }^{232}$ The common law seeks to strike a balance between these interests. Employers may obtain from their employees an agreement not to engage in competition with the employer for a limited time in a limited area after the employment terminates. Such negative covenants are specifically enforced. ${ }^{23 s}$

In cases like Wear-Ever, the fact that negative covenants were not included in the employment agreements signals that the employer did not believe that its interest in the employees' training and organization was sufficient to require contractual protection. It might be argued that imposing tort liability on the subsequent employer is beneficial because it reduces the costs of negotiating and enforcing negative covenants with each employee, particularly where a venture depends on a large number of employees; however, tort liability for interference only applies where a third party actively induces the departure. In the absence of negative covenants, nothing prevents employees from seeking alternative employment

tiff, successful on the breach of contract claim, also sued for tortious interference with its relationships with the crews. The court held that although it would not be tortious merely to break a contract and subsequently hire the crews, tort liability would follow if the breach was intended as a means of hiring the employees. Id. at 548, 145 P.2d at 311 . The court sustained an award of $\$ 4000$ above the contract damages "for the loss of plaintiff's trained organization, supervisors, good will and for general damages to the plaintiff's business." Id. at $540,548,145$ P.2d at 307,311 .

23: The problem is not unlike that resolved by the copyright and patent laws. A limited monopoly is offered as a balance between the need to encourage investment in innovation and the desirability of wide distribution and use of new ideas. English law used a similar device for the employee training problem in the Statute of Apprentices, which in effect gave the employer a seven-year monopoly over the employee's services at no cost, but left the employee free after that period to compete with the employer. 5 Eliz. 1, ch. 4, § 19 (156263). The economic role of covenants not to compete is examined at length in Kitch, The Law and Economics of Rights in Valuable Information, 9 J. Legal Stud. 683 (1980).

${ }^{23 s}$ D. DoBss, supra note $110, \S 12.26$. 
on their own initiative. An employer concerned about capturing the returns on his investment has the same incentive to seek negative covenants regardless of third-party tort liability. The absence of such covenants reflects the employer's determination that protecting his investment is not worth the costs of negotiating the agreements and casts doubt on the need for legal intervention. ${ }^{234}$

Apart from a desire to secure services, a competitor may entice another's employees to acquire access to proprietary material such as trade secrets, customer lists, or operating methods. Tort law protects proprietary information kept secret or disclosed in confidence, ${ }^{235}$ and liability for appropriation of such material can be based directly on trade secret law without resort to interference doctrine. The advantage of the more direct approach is that it highlights the proper inquiries: whether the information is protected, and if so, what remedy to impose.

The common law does not protect all information possessed by a business enterprise, and the law long has had difficulty separating the information and skills that "belong" to the employer from those that "belong" to the employee. ${ }^{236}$ If the defendant's purpose is to appropriate trade secrets by enticing the plaintiff's employee, none of the concerns traditionally related to the interference tort, such as the duration or validity of the contract and

234 Where negative covenants are breached, injunctive relief against the subsequent employer often is granted in addition to specific performance against the employee. This is not inconsistent with an unlawful means test for contract interference. The injunction against the subsequent employer is not based on his inducement of a breach of contract, but is ancillary to enforcement of the employees' contract. Where many employees are involved, it is more efficient to enjoin their employment than to enforce each negative covenant. There is some evidence that courts have recognized the different nature of the remedy applied to the subsequent employer in negative covenant cases. Courts have not required an act of inducement, but have enjoined the hiring of breaching employees even by innocent employers. In addition, most courts grant injunctive relief against the subsequent employer only if the negative covenant has been held valid, see, e.g., Haag Bros., Inc. v. Artex Int'l, Inc., 60 Ill. App. 3d 141, 145-46, 376 N.E.2d 636, 640 (1978); Custom Drapery Co. v. Hardwick, 531 S.W.2d 160, 165 (Tex. Civ. App. 1975), whereas the tort of inducing breach often is applied regardless of the validity of the breached contract.

${ }^{23 s}$ See Kewanee Oil Co. v. Bicron Corp., 416 U.S. 470, 474-76 (1974); 53 AM. Jur. 2D Master \& Servant § 104 (1970).

${ }^{236}$ See, e.g., Wexler v. Greenberg, 399 Pa. 569, 576-77, 160 A.2d 430, 433-34 (1960). For trade secrets and confidential information to be protected, they must be particular to the employer and not general secrets of the trade, or they must be particular to the employee. The factual difficulties in distinguishing trade secrets from general information are troublesome. See, e.g., Hulsenbusch v. Davidson Rubber Co., 344 F.2d 730, 734 (8th Cir. 1965), cert. denied, 382 U.S. 977 (1966). For a general discussion of the factual issues involved, see 56 C.J.S. Master \& Servant § 72b (1948). 
knowledge of its existence is or should be relevant. Similarly, the remedy should be designed to protect against or compensate for the loss of the proprietary information, not the loss of the employee. In most cases, injunctive relief should be directed against the use of the proprietary information rather than prohibiting the employment of the employee, although in some cases, an injunction against employment may be the only means of protecting the information. The calculation of a damage award also may be affected if the injury is the appropriation of the proprietary information and not of the employee.

It is possible to argue that in some employment cases, actual malice should result in liability. The success of an employer's business may depend on his employees, and this vulnerability can be exploited by those wishing to cause the employer injury. As in other competitive contexts, however, injury that results to the original employer from his inability to compete for the employee's services should not be compensable. On the other hand, there is no social gain from encouraging investment in personal malice. The difficulty is in drawing the line between competitive and noncompetitive motivations. Objective factors that tend to be inconsistent with competition should be required before liability is imposed. . $^{237}$

b. Inducing employer breach. The employer also can be induced to breach an employment contract. Several such cases are reported, involving for the most part contracts terminable at will. ${ }^{238}$ In some, the contract interference tort is used to incorporate actions based on misrepresentation, defamation, or privacy violations-clearly unlawful means. ${ }^{239}$ Although nothing precludes the possibility of competitive bidding for a place of employment-that is, a potential employee inducing the employer to fire another person and to offer the job to him-it is difficult to find such facts in the appellate cases. In such a case, the means would be lawful; as in all competitive contexts, tort liability should not be imposed.

237 If, for example, the inducer has no real need for the employee's skills or does not exploit those skills, the existence of malicious rather than competitive motivation seems more likely.

${ }^{238}$ See generally Annot., 79 A.L.R.3d 672 (1977); Annot., 29 A.L.R. 532 (1924). The early cases generally involved labor union pressure on employers to discharge nonunion workers. These cases have been largely preempted by federal labor legislation. See note 4 supra.

230 See, e.g., Birl v. Philadelphia Elec. Co., 402 Pa. 297, 301-03, 167 A.2d 472, 474-75 (1960) (alleging misrepresentation and slander). 
The most common fact pattern involves a third party who applies economic coercion-threatens to cancel an at-will contract or to discontinue a business relationship with the employer-unless the employee is fired. ${ }^{240}$ These cases raise issues slightly different from those raised by the competition cases. Because the third party usually has a right to terminate his relationship with the employer, and because the employee's contract is terminable at will, no actual breach of contract and no independently unlawful act occurs, ${ }^{241}$ yet liability in some cases seems appropriate. A few cases can be resolved by requiring objective proof of improper motivation. In these cases, the third party seeks to use his economic power for the sole purpose of injuring the employee by causing his discharge. In one case, the plaintiff's former employer, disgruntled by the plaintiff's change of employment, threatened the current employer with loss of patronage unless the plaintiff was fired. ${ }^{242}$ There is no social gain in encouraging this type of behavior, and as long as the evidence of motivation is clear, there is little risk of social loss. ${ }^{243}$

A more difficult case is Smith v. Ford Motor Co., ${ }^{244}$ in which Ford allegedly used its economic leverage on a dealership's principal stockholders to secure the discharge of the dealership's general manager. Ford's alleged purpose was to discourage the manager's participation in an organization of dealers formed to bargain collectively with Ford. ${ }^{245}$ The court, after observing that the shareholders had an absolute right to discharge the manager, ${ }^{246}$ nonetheless held that Ford could be held liable for contract interference

${ }^{240}$ E.g., Smith v. Ford Motor Co., 289 N.C. 71, 221 S.E.2d 282 (1976). See Annot., 79 A.L.R.3d 672 (1977).

241 A growing number of jurisdictions seem prepared to place legal restraints on an employer's power to discharge an at-will employee. See Note, Protecting At Will Employees Against Wrongful Discharge: The Duty to Terminate Only in Good Faith, 93 HaRv. L. Rev. 1816 (1980). Many of these "wrongful discharge" cases have been viewed as creating an action in tort rather than for breach of contract. See Yaindl v. Ingersoll-Rand Co., 422 A.2d 611, 618-19 (Pa. Super. Ct. 1980), and cases cited therein. See also Tameny v. Atlantic Richfield Co., 27 Cal. 3d 167, 610 P.2d 1330, 164 Cal. Rptr. 839 (1980). The appropriateness of casting a "wrongful discharge" as a tort is beyond the scope of this article. See generally Blades, Employment at Will vs. Individual Freedom: On Limiting the Abusive Exercise of Employer Power, 67 Colum. L. REv. 1404 (1967); Summers, Individual Protection Against Unjust Dismissal: Time for a Statute, 62 VA. L. REv. 481 (1976).

${ }^{242}$ See Hill Grocery Co. v. Carroll, 223 Ala. 376, 136 So. 789 (1931).

243 Proof that the inducer did not seek the position vacated by the discharged employee or did not seek to hire the employee would be evidence discounting a competitive purpose.

244 289 N.C. 71, 221 S.E.2d 282 (1976).

${ }^{245} I d$. at 83,221 S.E.2d at $289-90$.

${ }^{248}$ Id. at $80,82-83,221$ S.E.2d at $288-89$. 
unless it could show some "legitimate business interest" in seeking to prevent the manager's participation in the association. ${ }^{247}$ The Smith case is a good example of how the interference tort tends to prevent focus on the actual issue involved. The damage- termination of the employment-resulted from the use of economic power to influence behavior. Nothing in interference doctrine helps a court decide whether the prevention of a dealers' alliance is a legitimate business interest. Answering that inquiry is beyond the scope of this article, but the point is clear that with its focus on the nature of the interfering act, an unlawful means test is a more direct method of providing the answer.

In most cases of inducing wrongful discharge, the third party seeks some direct financial advantage from the employee's discharge. Courts have sought to distinguish permissible from impermissible conduct in these cases by applying the financial interest privilege of the Restatement (Second). ${ }^{248}$ That privilege allows a person with a financial interest in another's business to induce the other not to enter a prospective contractual relationship as long as the inducer does not employ wrongful means and acts only to protect his interest. Although the financial interest privilege helps explain why some interferences are not actionable, it does not explain the cases where even with some financial interest the inducer is held liable. These cases, like Smith, use the interference tort to avoid articulating a more precise and useful definition of unprivileged conduct, as two cases involving insurance companies illustrate. In Herron v. State Farm Mutual Insurance Co., ${ }^{249}$ an automobile liability insurer offered to settle with a plaintiff in a tort case if the plaintiff canceled a contingent fee contract with his lawyer. The lawyer successfully sued for interference with his contract. ${ }^{250}$ In Green v. Lundquist Agency, ${ }^{251}$ a trucking company's liability insurer threatened to cancel its insurance policy unless an

247 Id. at 94,221 S.E.2d at 296.

${ }^{248}$ Restatembnt (Second) of Torts $\$ 769$ (1979). See, e.g., Delaware State Bank v. Salmon, 548 P.2d 1024 (Okla. 1976).

240 56 Cal. 2d 202, 363 P.2d 310, 14 Cal. Rptr. 294 (1961).

${ }^{230}$ Similar to Herron are a number of cases in which an employer's insurance company was found liable for threatening to cancel a policy unless the employer coerced an employee to settle a claim against the insurer. See, e.g., London Guar. \& Accident Co. v. Horn, 206 Ill. 493, 69 N.E. 526 (1903); Hilton v. Sheridan Coal Co., 132 Kan. 525, 297 P. 413 (1931); see also Pino v. Trans-Atlantic Marine, Inc., 358 Mass. 498, 265 N.E.2d 583 (1970) (insurance company enjoined from interfering with plaintiff's employment by excluding him from insurance coverage).

2822 Mich. App. 488, 140 N.W.2d 575 (1966). 
accident-prone employee was fired. The employee was fired and sued the insurance company for contract interference, but was denied recovery. ${ }^{252}$

These cases are better understood by examining what the insurance company in each intended to accomplish by its interference. In Herron, the defendant was trying to reduce the loss it already had agreed to bear. The result would not be to increase. social wealth or to reduce social loss, but merely to redistribute wealth from the claimant to itself. On the other hand, in cases like Green, the interfering behavior is directed at reducing social losses that have not yet occurred or been allocated by contract. The behavior actually is part of the negotiation over what risks will be borne by the insurance company and at what price. Discouraging either poor driving or the employment of poor drivers reduces the total social loss from driving. Courts appear to have roughly drawn that distinction in practice by manipulating the concepts of malice and privilege. ${ }^{253}$ Under either rubric, the focus is properly on the defendant's acts and motivations, rather than on the plaintiff's interest in his contract.

Because the line between appropriate and inappropriate conduct is fine, the burden of proof is significant in these cases. The use of economic coercion in this manner-the threat of discontinued trade or cancellation of a contract-may represent a potentially significant loss to the person making the threat. It does not seem likely that such a person will act out of personal spite or seek to exploit unfairly his economic power in what must be isolated and short-run opportunities. If so, less restraint on socially useful activity will result if the plaintiff bears the burden of showing that the defendant acted improperly. ${ }^{254}$

${ }^{252}$ Similar cases have denied liability where a major creditor induced the discharge of an officer of the debtor, Delaware State Bank v. Salmon, 548 P.2d 1024 (Okla. 1976), and where a franchisor required the discharge of a franchisee's manager pursuant to a prohibition in the franchise agreement against hiring another franchisee's employees, Pearse v. McDonald's Sys. of Ohio, Inc., 47 Ohio App. 2d 20, 351 N.E.2d 788 (1975).

${ }^{253}$ See, e.g., Pino v. Trans-Atlantic Marine, Inc., 358 Mass. 498, 265 N.E.2d 583 (1970) (legal malice used to describe lack of privilege for insurance company to refuse coverage for employees who used particular attorney in past claims).

${ }^{254}$ See Burton, supra note 166, at $390 \mathrm{n} .97$ (arguing for a similiar allocation of the burden of proof of motivation in the analogous context of good faith performance of contracts). In some contexts, the plaintiff may be constitutionally required to bear the burden. For example, in Augustine v. Anti-Defamation League of B'Nai B'Rith, 75 Wis. 2d 207, 249 N.W.2d 547 (1977), the defendant complained to a radio station owner that his announcer, the plaintiff, had mishandled a talk show in a way that resulted in racial and religious slurs being aired. The station owner fired the plaintiff, who then sued the defendant for contract 
3. Corporate Officials' Liability for Inducing Breach by the Corporation. The interference tort has been used to attach personal liability to a corporate officer who induces his corporation to breach a corporate contract. ${ }^{255}$ If the corporation is seen as a separate entity, the tort superficially seems applicable, but because corporations can act only through officers, potential tort liability would result whenever a corporation breached its contract. The courts' resolution of this dilemma reinforces powerfully the analysis offered in this article as to the proper application of the interference tort.

Where a disappointed promisee sues an officer for inducing corporate breach, most jurisdictions have conditioned officer immunity on a finding of "good faith." Thus, where the corporate officer uses lawful means and acts within the scope of his authority, on behalf and for the benefit of the corporation, courts universally have refused to find him personally liable for inducing a corporate breach. ${ }^{258}$ This grant of immunity and its asserted justification confirm that contract breach is an economic event, not an immoral act. Officer liability for inducing breach presumably would reduce the number of corporate contract breaches, yet the courts refuse to impose liability, expressly so as not to discourage officer actions that lead to breach. ${ }^{257}$ At least one court has recog-

interference. Although the court did not reach the privilege issue, finding that there was no purpose to disrupt the plaintiff's contract, the facts demonstrate how interference with contracts by persuasion may raise first amendment issues.

${ }^{235}$ See, e.g., Seven D. Enterprises, Ltd. v. Fonzi, 438 F. Supp. 161 (E.D. Mich. 1977) (applying Michigan law); Chanay v. Chittenden, 115 Ariz. 32, 563 P.2d 287 (1977).

2so See generally H. Ballantine, Corporations § 112, at 275-76 (1946); 3 W. Fletcher, Cyclopedia of the Law of Private Corporations \$ 1001, at 540-41 (rev. perm. ed. 1975 \& Supp. 1980). The same immunity has been applied to agents acting for individual principals, Kvenild v. Taylor, 594 P.2d 972, 977 (Wyo. 1979), and to public officials alleged to have disrupted a government agency's contract, Idlehour Dev. Co. v. City of St. Charles, $88 \mathrm{ml}$. App. 3d 47, 52, 409 N.E.2d 544, 548 (1980).

Corporate officers' good faith immunity is based on several arguments. First, the officer is not a stranger to the corporation but its representative. Second, if the officer were liable, the corporation would be liable under respondeat superior and therefore would be liable in tort for all contract breaches. Officers also may have broad indemnity rights against the corporation for personal liability. See Model Bus. CoRP. Act $\$ 5$ (ABA-ALI 1979) (indemnity for all liability if the officer, director, employee, or agent "acted in good faith and in a manner he reasonably believed to be in or not opposed to the best interests of the corporation."). Finally, personal liability arguably would disrupt the fiduciary relationship between officer and corporation and would make it difficult for officers to give disinterested advice. See Wampler v. Palmerton, 250 Or. 65, 74-75, 439 P.2d 601, 606 (1968). See generally Avins, Liability for Inducing a Corporation to Breach Its Contract, 43 Connell L.Q. 55 (1957); 89 U. PA. L. REv. 250 (1940).

${ }^{257}$ See, e.g., Wampler v. Palmerton, 250 Or. 65, 75, 439 P.2d 601, 606 (1968). 
nized explicitly that part of the risk a promisee accepts in contracting with a corporation is that the corporation may be advised by its officers to breach. ${ }^{258}$

At the same time, the good faith standard has not always been applied consistently with efficient breach theory. A few cases, for example, suggest that an officer might be liable for interference if he is motivated by his own rather than the corporate interest. ${ }^{289}$ Under these cases, a showing that the officer benefited from the corporate breach is sufficient to attach tort liability, even though the corporation also benefited from the breach. ${ }^{280}$ Logically extended, a personal benefit test would attach liability in all cases, because all corporate officer behavior presumably is dictated by self-interest: ${ }^{261}$ to the extent the corporation succeeds, it is likely that the officer will succeed, and in closely held corporations, the

${ }^{258}$ Wampler v. Palmerton, 250 Or. 65, 75, 439 P.2d 601, 606 (1968) ("The person contracting with the corporation cannot reasonably have any contractual expectancy that does not take into consideration the fact that the corporation may be advised to breach the contract, in accordance with its interest, by a person whose duty it is to do so.").

${ }^{268}$ E.g., Seven D. Enterprises, Ltd. v. Fonzi, 438 F. Supp. 161, 164 (E.D. Mich. 1977) (applying Michigan law); Chanay v. Chittenden, 115 Ariz. 32, 37-38, 563 P.2d 287, 292-93 (1977).

${ }^{260}$ For example, if the plaintiff is the exclusive distributor of the $X Y Z$ Corporation, and $T P$, an $X Y Z$ officer, induces the corporation to breach the agreement and to install $T P$ as distributor in the plaintiff's place, it may be that $T P$ is a better distributor than the plaintiff. See A.S. Rampell, Inc. v. Hyster Co., 1 Misc. 2d 788, 792, 148 N.Y.S.2d 102, 107 (Sup. Ct. 1955), modified on other grounds, 2 A.D.2d 739, 153 N.Y.S.2d 176 (1956) (mem. op.); 3 N.Y.2d 369, 144 N.E.2d 371, 165 N.Y.S.2d 475 (1957). The trial court suggested that with facts similar to the example, a benefit test would have imposed liability if the officer had taken the distributorship for himself and no benefit had accrued to the firm.

${ }^{281}$ Corporate officer liability is usefully contrasted with a shareholder's liability for inducing breach. The shareholder's liability generally is evaluated under the privilege to protect one's financial interest or investments. Thus, shareholders in two New York cases were granted immunity for inducing breaches of their corporations' contracts. Felsen v. Sol Cafe Mfg. Corp., 24 N.Y.2d 682, 687, 249 N.E.2d 459, 461, 301 N.Y.S.2d 610, 613-14 (1969) (evidence showed that the defendant corporation's sole stockholder was motivated by concern for its internal management in discharging the plaintiff and not by malice); Morrison v. Frank, 81 N.Y.S.2d 743, 744 (Sup. Ct. 1948) (allegation that the defendant acted solely for his own benefit negated another claim that he acted "maliciously"). As one would expect, there are cases imposing liability where the shareholder uses independently tortious means. E.g., Morgan v. Andrews, 107 Mich. 33, 64 N.W. 869 (1895) (fraud). See also Pennington Trap Rock Co. v. Pennington Quarry Co., 22 N.J. Misc. 318, 38 A.2d 869 (Sup. Ct. 1944). The Restatement (Second) codifies a financial interest privilege to cause another not to enter into a prospective contractual relationship as long as the actor does not use wrongful means to protect his interest from being prejudiced. RESTATEMENT (SECOND) OF TORTS $\$ 769$ (1979). Interference with an existing contract is not privileged per se, however, but must be evaluated in the same way as other contract interferences, by balancing all the factors to determine if the action was "improper." Id. comment b. 
officer may be the direct beneficiary of any corporate success. ${ }^{262}$ From the standpoint of allocational efficiency, a personal benefit test is unwarranted. If the corporation gains and the promisee is compensated adequately for his expectancy, the allocation of social resources has been improved; it is irrelevant that the officer also gains.

Most courts interpreting the good faith standard have limited an officer's liability to those cases where his behavior is adverse to the corporation's interest. ${ }^{263}$ Social welfare analysis suggests that liability may be appropriate in this instance. If the result of breach is gain to the officer and loss to the corporation, there is no assurance that breach will generate a net social gain; the result may be only to transfer the proceeds from the original contract to the of-

282 See, e.g., Wampler v. Palmerton, 250 Or. 65, 439 P.2d 601 (1968). The difficulties of applying any good faith test in the context of a closely held corporation are illustrated by Olympic Fish Prods., Inc. v. Lloyd, 93 Wash. 2d 596, 611 P.2d 737 (1980). The plaintiff contracted to purchase the Yankee Corporation's yearly production of roe herring. The defendant and his wife held fifty percent of Yankee's stock; the defendant's former sister-inlaw held the other fifty percent. Yankee did not operate fishing boats, but purchased fish from independently owned boats, most of which were owned and operated by the defendant and his relatives. When the market price for fish increased, the defendant as officer of the corporation breached the contract with the plaintiff and sold to third parties. The plaintiff sued the corporation for breach and the defendant in tort. The court accepted a definition of "good faith" as requiring an intention to benefit the corporation. Noting that the defendant would benefit personally from the increased price captured by Yankee and from the increased price he could charge Yankee for fish, the court held that the case presented a material question of disputed fact and reversed summary judgment for the defendant.

Officer liability may be warranted where a defendant undercapitalizes the corporation and thereby prevents the plaintiff from recovering any of his contract expectancy losses on his breach of contract claim. By doing so, the defendant could get the benefit both of contract price and any market price increases. There would be no social gain from breach, but merely a redistribution of wealth from the plaintiff to the defendant. This was not the case, however, in Olympic, and in any event, no independent tort of contract interference is necessary for fraudulent undercapitalization. Corporation law already attaches personal liability to shareholders in such cases, and officers are liable personally for fraud if they misrepresent the corporate structure to the plaintiff. See generally H. Ballantine, CoRporations $\$ \$ 127-$ 129, at 298-303 (1946). These doctrines seem to have struck the difficult balance between protecting the limited liability of shareholders and officers and the expectations of corporate creditors. A tort doctrine that focuses exclusively on the officers' acts may disrupt that balance.

Short of some fraudulent attempt to escape the contractual obligation, it is not easy to determine whether the defendant in Olympic acted for the corporation's benefit or for his personal benefit. To the extent the corporation did in fact suffer by this transaction, the defendant's sister-in-law seems to have had sufficient incentive to rectify the wrong. See also Manufacturers Hanover Trust Co. v. Kearney Chems., Inc., 468 F. Supp. 1107 (D. Del. 1979), in which it was alleged that a closely held corporation interfered with its major shareholder's contract.

${ }^{203}$ See, e.g., Wampler v. Palmerton, 250 Or. 65, 439 P.2d 601 (968). 
ficer. Because this redistribution creates no social gain, efficient breach theory would not stand in the way of tort liability. On the other hand, acts adverse to the corporation already violate the officer's duty of loyalty, rendering him liable for damages resulting to the corporation. ${ }^{264}$ Use of the contract interference tort thus masks the real issue, which is whether liability for breach of the duty of loyalty to the corporation should be extended to injured third parties. Adoption of a general principle allowing third parties to recover for economic injury resulting from officer misconduct would create the potential for expansive liability without self-defining limits. To restrict liability to the promisee whose contract is breached provides some limit when the officer's behavior is directed specifically at the breach of a single contract. Where the officer's misconduct is directed not at a specific contract, however, but at the economic health of the corporation, resulting in largescale dislocations and breaches of contract, courts understandably might be reluctant to impose liability. Courts might use the interference tort to limit liability to those cases in which the defendant's behavior is directed specifically at the plaintiff's contract. To this extent, the interference tort serves a useful function. It is less clear, however, that liability ought to be imposed at all. Whether the officer's behavior adversely affects the corporation may be so ambiguous that only the corporation or its shareholders should be entitled to enforce the duty of loyalty. ${ }^{265}$

284 G. Hornstein, Corporation Law and Practice $\$ 432$, at 528 (1959).

${ }^{208}$ The Illinois Supreme Court appears to have adopted a similiar test for liability in corporate contexts. In Swager v. Couri, 77 Ill. 2d 173, 188, 395 N.E.2d 921, 927 (1979), the court commented:

Much more difficult questions are posed, however, when a director, officer or shareholder of a corporation is alleged to have tortiously interfered with the corporation's contractual relations. What may at first blush appear to constitute the misuse of the corporate form as a device to defraud the unwary, may also, on closer inspection, be revealed to involve more subtle questions of the scope of the concept of "limited liability" as it applies to investors and managers of closely held corporations; and of the duties and reasonable expectations of persons negotiating arm's-length agreements in the robust environment of daily commercial life.

The precise test adopted in Swager is unclear, but at least one lower court has interpreted the case as rejecting good faith and focusing instead on the lawfulness of the defendant's acts as defined by the Illinois Business Corporation Act, ILl. REv. Star. ch. 32, §§ 157.1-.167 (1979). See Idlehour Dev. Co. v. City of St. Charles, 88 Ill. App. 3d 47, 50, 409 N.E.2d 544, 547 (1980).

Swager involved rather dramatic facts. The plaintiff architects contracted with a closely held corporation to design a nursing home. The directors subsequently dissolved the corporation and built the house using other architects. At the time they signed the agreement, the plaintiffs were aware of the corporate structure and of the directors' unwillingness to assume 
In cases where the officer acts with express malice-an intent to harm the promisee out of spite or ill will-application of the interference tort obscures the proper analysis. As in other contexts, the proper question is whether the interfering acts are independently unlawful or objectively inconsistent with competition and allocational efficiency. Malicious acts by officers that are adverse to the corporation's interest can be discouraged by corporate enforcement. On the other hand, if the officer acts to benefit the corporation, the corporation under respondeat superior would be liable directly in tort, ${ }^{286}$ and the case would be no different from any case in which a promisor maliciously breaches an agreement. Casting the case as an interference tort only confuses the issues. ${ }^{267}$

Nothing in corporate breach requires relaxation of the unlawful means test. Defendants still may sue the corporation in contract in cases where the officer induces breach in the corporate interest, and alternative grounds for liability, such as violations of a duty of loyalty, appear to provide disincentives for inefficient or reprehensible behavior in cases where the officer acts contrary to the corporate interest. ${ }^{268}$

4. Brokerage Contracts. Some brokerage contracts are exclusive agreements entitling the broker to a commission if the property is sold. More commonly, the broker earns a commission only if he is the procuring cause of the sale. Some contracts require the sale to be consummated during the term of the contract; others entitle the broker to his commission even if the sale is made after the contract terminates as long as the ultimate buyer was "procured" by the broker during the term of his contract. In many instances, brokers do not have contracts, but rely on implied or ad hoc commitments by the seller to pay if the broker procures a buyer. Particularly in real estate transactions, the facts are often

personal liability on the contract. 77 Ill. $2 \mathrm{~d}$ at 178-82, 395 N.E.2d at 922-24.

${ }^{268}$ See W. Prosser, supra note $2, \S 70$, at 464.

${ }^{287}$ Tash v. Houston, 74 Mich. App. 566, 254 N.W.2d 579 (1977), is an example of a case where use of the interference tort diverts attention from the nature of the defendant's act. The plaintiff was fired from her at-will employment with a local labor union when she refused the sexual advances of the local's president. The court reversed summary judgment for the defendant, applying the interference tort and the good faith privilege. At trial the defendant was obliged to show that the discharge resulted from union rather than personal interests. A more straightforward examination of whether sexual harassment constitutes a tort seems to be the superior approach.

${ }^{268}$ For a case adopting an approach similar to the approach advocated here and citing an earlier draft of this article, see Dependahl v. Falstaff Brewing Corp., 653 F.2d 1208, 1217 (8th Cir. 1981). 
confused, and disputes after the fact are common. Whether a broker "procured" the ultimate purchaser or whether the seller agreed to pay a commission are often contested. Many jurisdictions require brokerage contracts to be in writing to reduce fraudulent claims for commission. ${ }^{269}$ This in turn creates incentives for the broker to find alternative means of recovery, such as suing the buyer or seller or both for interference with his expectancy of a commission. Courts thus must craft rules that both prevent fraudulent claims by brokers and prevent buyers or sellers from unjustly appropriating brokers' efforts. A general tort of interference with economic expectancy, though available and used for this purpose, seems too blunt an instrument.

Efficient breach theory does not justify avoidance of the brokerage commission by the parties to the transaction. The buyer and seller are not seeking to produce social gains; they merely are attempting to transfer the broker's commission to themselves. A broker's role is to reduce the search costs of buying and selling; to the extent the law allows parties to appropriate the broker's efforts without paying a commission, the incentives to act as broker are reduced, and the costs of buying and selling are increased.

An interference with the broker's commission results when a potential buyer, procured by the broker, attempts to deal directly with the seller to avoid the commission. In some cases, the seller is unaware that the broker procured the buyer, ${ }^{270}$ and often the buyer represents to the seller that no broker is involved.271 The buyer may even agree to indemnify the seller for any commissions subsequently determined to be owing. ${ }^{222}$ These facts do not necessarily represent bad faith on the buyer's part, because if brokerinitiated negotiations are abandoned in good faith and the buyer subsequently decides to reopen them and to purchase the property, there is authority for the proposition that the broker is not the "procuring" cause and thus not entitled to a commission. ${ }^{273}$ On the other hand, it is likely in most cases that the buyer simply wants to avoid paying the commission.

Some purchasers attempt to avoid the commission by purchas-

28012 AM. JUR. 2D Brokers $\S 41$, at 803 (1964).

${ }^{270}$ E.g., Franklin v. Brown, 159 So. 2d 893, $894-95$ (Fla. Dist. Ct. App. 1964).

${ }^{271}$ E.g., Kennedy v. George Cully Real Estate, Inc., 296 So. 2d 551, 553 (Fla. Dist. Ct. App. 1974).

${ }^{272}$ E.g., Retzky v. J.A. Cantor Assocs., Inc., 192 So. 2d 24, 26 (Fla. Dist. Ct. App. 1966).

${ }^{273}$ E.g., Miller v. Jones, 54 Tenn. App. 31, 37-38, 387 S.W.2d 627, 630 (1965). See 12 AM. JuR. 2D Brokers § 223, at 963 (1964). See also Annot., 27 A.L.R. 2d 1348 (1953). 
ing the property through a straw party, with ${ }^{274}$ or without ${ }^{275}$ the seller's knowledge. The mere fact that the property was purchased by a third person and subsequently transferred to the procured buyer need not imply bad faith, however, for it is possible that the procured buyer withdrew from negotiations in good faith and subsequently determined to renew his bid to the subsequent purchaser of the property.

What makes all of these cases difficult is that in those cases where liability seems appropriate, the defendant's acts do not interfere with the commission contract. The broker's commission is conditioned on sale of the property to a buyer he procures; the defendant's behavior fulfills that condition. In every case of this type, the broker has a contractual claim against the seller. ${ }^{278}$ The person most likely to suffer loss is the seller, who may have reduced the selling price of the property in reliance on the representation that no brokerage commission is owed.277

It seems clear from this analysis that fraud, not interference with the brokerage contract, is the relevant legal issue. Where the seller and buyer conspire to deprive the broker of his commission, the buyer will misrepresent to the broker that he does not intend to purchase the property. ${ }^{278}$ The seller in turn may be under a duty to inform the broker that a condition precedent to the broker's entitlement to his commission has been fulfilled; failure to do so may be fraud on the seller's part. ${ }^{279}$ Where the seller is ignorant of the buyer's attempt to avoid the commission, the buyer may misrepresent to the seller that no broker is involved. ${ }^{280}$ In all of these cases,

${ }^{274}$ E.g., California Auto Court Ass'n v. Cohn, 98 Cal. App. 2d 145, 219 P.2d 511 (1950).

275 E.g., Franklin v. Brown, 159 So. 2d 893, 895 (Fla. Dist. Ct. App. 1964).

${ }^{278}$ A few cases have denied tort liability, even where the purchaser is considered guilty of fraud, because no damage occurs. A straw man is deemed the agent of the actual purchaser, and because the property was sold to a broker-procured purchaser, the broker has his contract claim. Backman v. Guiliano, 331 Mass. 231, 232, 118 N.E.2d 78, 79 (1954); McAuslan \& Nutting, Inc. v. Futurity Thread Co., 254 Mass. 216, 218, 150 N.E. 96 (1926); Madden v. Shane, 185 S.W. 908, 910-11 (Tex. Civ. App. 1916).

${ }^{272}$ In Madden v. Shane, 185 S.W. 908, 910 (Tex. Civ. App. 1916), the court suggested that if the seller was entirely innocent of the fraud and sold the property at a reduced price, he would not be liable for the commission.

278 This misrepresentation was recognized as supporting liability in Barnett v. Eubanks, 105 Ga. App. 749, 752, 125 S.E.2d 571, 573 (1962).

${ }^{279}$ See RESTATEment (SEcond) op TorTs $\$ 551(2)(a)$ (1979). The court in Madden v. Shane, 185 S.W. 908, 910-11 (Tex. Civ. App. 1916) suggested that a seller would be under a duty to investigate if he had notice that a straw man might be used to avoid a commission.

${ }^{280}$ In Franklin v. Brown, 159 So. 2d 893, 895 (Fla. Dist. Ct. App. 1964), the buyer failed to disclose to the seller that the seller would owe a broker's commission. The court used this fraud as support for reinstating the broker's complaint against the buyer. 
the parties rely on misrepresentations to their injury.

A cause of action for fraud also highlights the proper measure of damages. As a result of the misrepresentations, the broker may engage in additional effort to find a buyer. These costs should be recoverable. The broker also may have waited to collect his commission (because he did not know it was owing) until after the seller became insolvent or otherwise unable to pay. If so, it does not appear unreasonable to allow recovery of the commission from the buyer without proof that the seller is unable or unwilling to pay. ${ }^{281}$ The fraud also may support punitive damages. ${ }^{282}$

Basing the cause of action on fraud also simplifies the cases where the broker's commission is based on an oral contract. To allow claims without some hint of misrepresentation would upset the policies behind the statute of frauds and likely would lead to more fraudulent claims by brokers. Proof of fraud by the buyer or seller, however, should be sufficient circumstantial evidence from which to infer that a commission was part of the initial agreement. $^{283}$

In the absence of proof of fraud, application of the interference tort can have untoward consequences in upsetting or circumventing carefully developed rules for regulating transactions. Allen $v$. Powell ${ }^{284}$ illustrates the difficulty. The plaintiff, a broker, earned a $\$ 60,000$ commission by consummating a lease of land between the owners and Lee Brothers ("Lee"). The commission was to be paid from the rental income. Subsequently, the original owners became financially embarrassed and negotiated the sale of the property to Lee. The terms of the sale provided that the purchase money was to be paid by Lee to various creditors of the owners, but not to the plaintiff. The plaintiff alleged that the transaction

281 Where the seller is involved in the fraud, the buyer and seller may be viewed as joint tortfeasors, allowing recovery of the full commission from the buyer. Where the seller is innocent, he will have a claim against the buyer for fraud if he pays the commission to the broker; allowing the broker a direct suit against the buyer saves litigation costs.

282 C. McCormick, Damages § 81, at 286 (1935).

28s In McCann v. Biss, 65 N.J. 301, 310-11, 322 A.2d 161, 166 (1974), the court recognized that a suit against the seller for tortious interference where the contract claim for the commission is barred by the statute of frauds seeks to undercut the statute and should not be allowed even though the owner might be liable on the independent grounds of deceit if fraud was committed. On the other hand, it appears that California in some circumstances would allow recovery against the seller for intentional interference with prospective economic advantage even if the contract was unenforceable. See Buckaloo v. Johnson, 14 Cal. 3d 815, 537 P.2d 865, 122 Cal. Rptr. 745 (1975). See generally Annot., 96 A.L.R.3d 1294 (1979).

284 248 Cal. App. 2d 502, 56 Cal. Rptr. 715 (1967). 
left the owner insolvent and unable to pay the commission, and he secured a judgment against the owners for the commission. The plaintiff also alleged that Lee obtained the land for an amount not including the plaintiff's commission and that Lee intended to deprive the plaintiff of his commission. ${ }^{285}$ The trial court granted a general demurrer to these allegations, ${ }^{288}$ but the appellate court reversed and held that a cause of action was stated for inducing breach of the commission contract. ${ }^{287}$

A creditor like the plaintiff in Allen who believes he is being denied his proper share of his debtor's assets has two alternatives. He may contest any transfer of assets to other creditors as representing a fraudulent conveyance ${ }^{288}$ or he may force his debtor into bankruptcy and claim that any conveyance made within the statutory period prior to bankruptcy is a preference. ${ }^{288}$ On the evidence available to the court in Allen, however, the transaction between the owners and Lee was not fraudulent. ${ }^{280}$ Although payments to selected creditors would be preferences in bankruptcy if made within the statutory period, bankruptcy would still entitle the plaintiff to recover only a proportional part of the debt and would not entitle him to recover from Lee. By using the interference tort, the plaintiff in Allen was able to secure an advantage over other

${ }^{285}$ Id. at 504-05, 56 Cal. Rptr. at 718.

28s Id. at 504, 56 Cal. Rptr. at 717.

${ }^{287}$ Id. at 509, 56 Cal. Rptr. at 720 .

${ }^{28 s}$ In a general sense, a fraudulent conveyance is a transfer of property by a debtor for less than fair consideration that results in his insolvency or otherwise is designed to defraud creditors. See generally Uniform Fraudul.snt Conveyance Act (1918); 1 \& 2 G. GlenN, Fraudulent Conveyances and Preferences (1940). A trustee in bankruptcy may also upset fraudulent conveyances. 11 U.S.C. $\S 548$ (Supp. III 1979).

2s9 Federal law gives the trustee in bankruptcy the power to avoid preferential transfers. 11 U.S.C. \$ 547(b) (Supp. III 1979). Many states also have antipreference statutes. See S. Riesenfeld, Cases and Materials on Creditors' Remedizs and Debtors' Protection 488-89 (3d ed. 1979).

200 Normally the sale of an asset owned by the debtor is not fraudulent as long as a fair price is received in return. See Unirorm Fraudulent Conveyance Act §§ 4-6 (1918); see generally 1 G. GLENN, supra note 288, $\S \S 273-290$. The Bankruptcy Act exempts from the preference statute most transfers for new value. 11 U.S.C. \& 547(c) (Supp. III 1979). This result reflects the fact that the overall estate of the debtor is not diminished and no creditor injured by such transfers. Thus, in Allen v. Powell, 248 Cal. App. 2d 502, 56 Cal. Rptr. 715 (1967), the transaction with Lee was not a fraudulent conveyance as long as the purchase price represented the fair market value of the land-a factor not examined by the court. Similarly, it is not normally a fraudulent conveyance to make payment to some creditors and not others, even though such payments lead the debtor into insolvency. The Uniform Act defines fair consideration to include the satisfaction of an antecedent debt. UNIFORM Fraudulent Conveyance Act $\$ 3$ (1918). In Allen, the stipulation that the purchase price be paid to designated creditors was not a fraudulent conveyance. 
unpaid creditors of the owners. Although the debt involved a transaction concerning the land in question, it did not arise from the sales transaction between the owner and the defendant, and the plaintiff should be no better off than any other creditor of the original owner. ${ }^{201}$ If extended to its logical conclusion, the analysis would make Lee liable to any unpaid creditor of whom it had notice. By focusing on the result-the plaintiff's disrupted expectancy-rather than the defendant's behavior, the court imposed liability at odds with established doctrine regulating debtor-creditor relationships and achieved no visible objective that justified the departure. An unlawful means test would avoid such a result.

\section{Conclusion}

The tort of interference with contract or prospective relationships is applied in widely divergent settings, yet courts disagree on important fundamentals of the tort and its proper application. I have sought to show that careful attention to the proper role of tort and contract doctrine assists in isolating the issues in these cases and in clearing the path to their solution. Where the defendant's act of interference is independently unlawful, tort objectives predominate; where the defendant's behavior is lawful except for the resulting interference, tort theory should reflect and remain consistent with contract policies. In cases of unlawful acts, the issue is viewed more properly as the scope of liability for unlawful behavior; the interference tort, with its requirement that the defendant's intention focus on the plaintiff's relationship, provides a convenient method of limiting liability to a narrow range of economic harm. In cases of otherwise lawful acts, tort liability works at cross-purposes with contract policies. Contract remedies seem to promote efficiency, whereas the addition of inducer liability inhibits efficient outcomes. Between these two classes of cases is an intermediate class where courts focus on the motive behind the defendant's act, imposing liability where malice is shown. The ambiguity of a malice standard and the inevitable costs of applying it suggest that liability should be based only on objective indicia of activity producing social loss. By confining the tort to cases of independently unlawful acts or cases where improper motive can be

291 For a factual situation similar to Allen except that the defendant did not have knowledge of the debt, see Tamposi Assocs., Inc. v. Star Market Co., 119 N.H. 630, 406 A.2d 132 (1979). The court denied what it regarded as "this extended and remote means of recovery." Id. at 633, $406 \mathrm{~A} .2 \mathrm{~d}$ at 135. 
discerned from objective facts, social welfare can be enhanced.

Even with the doctrinal confusion, explicit adoption of the unlawful means test would alter the outcomes in only a small number of cases. In many of the recurrent patterns to which the tort is applied, the underlying behavior is independently unlawful, even though courts do not explicitly base their decisions on this factor. The surprising degree to which the actual outcomes of decided cases is consistent with the analysis offered here gives some confidence that it describes the intuitive judgments of appellate courts, even though these judgments are expressed in language far broader than is necessary or appropriate. Making these intuitions more explicit by adoption of an unlawful means test has two advantages. First, it will reduce the number of cases that actually diverge from the analysis. Second, and perhaps more significantly, it will reduce the chilling effect that the current ambiguously stated doctrine must have on socially beneficial activity. 